\title{
An improved, automated whole air sampler and gas chromatography mass spectrometry analysis system for volatile organic compounds in the atmosphere
}

\author{
Brian M. Lerner ${ }^{1,2, a}$, Jessica B. Gilman ${ }^{2}$, Kenneth C. Aikin ${ }^{1,2}$, Elliot L. Atlas ${ }^{3}$, Paul D. Goldan ${ }^{2, *}$, Martin Graus ${ }^{4}$, \\ Roger Hendershot ${ }^{5}$, Gabriel A. Isaacman-VanWertz ${ }^{6, b}$, Abigail Koss ${ }^{1,2}$, William C. Kuster ${ }^{1,2, *}$, Richard A. Lueb ${ }^{5}$, \\ Richard J. McLaughlin ${ }^{1,2}$, Jeff Peischl ${ }^{1,2}$, Donna Sueper ${ }^{7}$, Thomas B. Ryerson ${ }^{2}$, Travis W. Tokarek ${ }^{8}$, \\ Carsten Warneke $^{1,2}$, Bin Yuan ${ }^{1,2}$, and Joost A. de Gouw ${ }^{2}$ \\ ${ }^{1}$ Cooperative Institute for Research in Environmental Sciences, Boulder, CO, USA \\ ${ }^{2}$ NOAA Earth System Research Laboratory, Chemical Sciences Division, Boulder, CO, USA \\ ${ }^{3}$ University of Miami, Rosenstiel School of Marine and Atmospheric Science, Miami, FL, USA \\ ${ }^{4}$ Universität Innsbruck, Institut für Atmosphären- und Kryosphärenwissenschaften, Innsbruck, Austria \\ ${ }^{5}$ National Center for Atmospheric Research, Division of Atmospheric Chemistry, Boulder, CO, USA \\ ${ }^{6}$ University of California at Berkeley, Department of Environmental Science, Policy, and Management, Berkeley, CA, USA \\ ${ }^{7}$ Aerodyne Research, Inc., Billerica, MA, USA \\ ${ }^{8}$ University of Calgary, Department of Chemistry, Calgary, AB, Canada \\ ${ }^{a}$ current address: Aerodyne Research, Inc., Billerica, MA, USA \\ b current address: Virginia Tech, Department of Civil and Environmental Engineering, Blacksburg, VA, USA \\ * retired
}

Correspondence to: Brian M. Lerner (blerner@aerodyne.com)

Received: 17 June 2016 - Published in Atmos. Meas. Tech. Discuss.: 11 July 2016

Revised: 24 December 2016 - Accepted: 6 January 2017 - Published: 26 January 2017

\begin{abstract}
Volatile organic compounds were quantified during two aircraft-based field campaigns using highly automated, whole air samplers with expedited postflight analysis via a new custom-built, field-deployable gas chromatography-mass spectrometry instrument. During flight, air samples were pressurized with a stainless steel bellows compressor into electropolished stainless steel canisters. The air samples were analyzed using a novel gas chromatograph system designed specifically for field use which eliminates the need for liquid nitrogen. Instead, a Stirling cooler is used for cryogenic sample pre-concentration at temperatures as low as $-165^{\circ} \mathrm{C}$. The analysis system was fully automated on a $20 \mathrm{~min}$ cycle to allow for unattended processing of an entire flight of 72 sample canisters within $30 \mathrm{~h}$, thereby reducing typical sample residence times in the canisters to less than 3 days. The new analytical system is capable of quantifying a wide suite of $\mathrm{C} 2$ to $\mathrm{C} 10$ organic compounds at part-per-trillion sensitivity. This paper describes the sam-
\end{abstract}

pling and analysis systems, along with the data analysis procedures which include a new peak-fitting software package for rapid chromatographic data reduction. Instrument sensitivities, uncertainties and system artifacts are presented for 35 trace gas species in canister samples. Comparisons of reported mixing ratios from each field campaign with measurements from other instruments are also presented.

\section{Introduction}

Volatile organic compounds (VOCs), chemical species consisting primarily of carbon, hydrogen and oxygen, are ubiquitous and important components of the atmosphere (Glasius and Goldstein, 2016; Schultz et al., 2015). VOCs are fundamental to the photochemical formation of ozone and secondary organic aerosol (de Gouw et al., 2005; Edwards et al., 2014; Kanakidou et al., 2005; Trainer et al., 2000) 
and can have direct and indirect effects upon both air quality and global climate (Hoyle et al., 2009; Monks et al., 2015). Measurements of VOCs can be used to identify and quantify emission sources and photochemical aging processes (Fortin et al., 2005; Mckeen and Liu, 1993; Warneke et al., 2012). Important primary sources for VOCs can vary by location and season - emissions from biogenic, biomass burning, urban/industrial and oil/natural gas extraction have all been characterized by this laboratory and others using in situ gas chromatography-mass spectrometry (GC-MS) (Gentner et al., 2014; Gilman et al., 2013, 2015; Goldan et al., 1995, 2000; Hornbrook et al., 2011).

The use of gas chromatography followed by mass spectrometry for the analysis of VOCs is a well-established technique due to its superior selectivity and sensitivity compared to other chromatograph detection methods (McClenny et al., 1996). For GC-MS, sensitivities can be enhanced by preconcentration of the analytes, commonly by means of adsorbent(s) or cryogenic trapping (Brown and Purnell, 1979; Greenberg et al., 1994; McClenny et al., 1984; Woolfenden, 2010). Cryogenic sample pre-concentration allows high vapor pressure VOCs and halocarbons to be trapped without the use of strong adsorbents that can produce significant artifactual responses (Apel et al., 2003b; Sive et al., 2005); however, sufficient volumes of liquid cryogen (e.g., liquid nitrogen) can be difficult to obtain at remote field locations (Tanner et al., 2006; Wang et al., 2012). Cryogen-free systems that allow for low-temperature sample trapping by means of Peltier or refrigeration units suffer from slow temperature response times, lack of portability due to size and weight and/or insufficiently low trap temperatures to allow trapping of the most volatile gases (e.g., ethane) without adsorbents (Hopkins et al., 2011; Liu et al., 2016; Miller et al., 2008; Sive et al., 2005; Tanner et al., 2006; Wang et al., 2014).

Stirling coolers offer an alternative cooling technology for cryogenic sample pre-concentration. Conceptually, the Stirling cooler consists of a sealed cylinder filled with a gas (e.g., helium), with a piston that compresses and expands the gas and a displacer that moves the gas from one end of the cylinder to the other out of phase with the piston (de Waele, 2011). Cooler performance is measured in watts of lift capacity, a measure of the amount of heat transfer from one end of the cylinder to the other while maintaining a constant temperature at the cold end. In this application, the warm end of the cooler is subsequently cooled with forced air. The Stirling cooler features low weight and size, modest power consumption and maintenance-free operation but at the cost of low lift capacity (ter Brake and Wiegerinck, 2002). Stirling coolers have been used by at least two other gas chromatography groups for air sample pre-concentration, but previous examples either required an extended ( $20 \mathrm{~min})$ cooling cycle to achieve cryogenic trapping temperature (Oliver et al., $1996)$ or were operated at warmer $\left(-80^{\circ} \mathrm{C}\right)$ than cryogenic temperatures (Sala et al., 2014; Obersteiner et al., 2016). For the work presented here, a novel sample trap design has been developed utilizing a Stirling cooler that is capable of achieving cryogenic trapping temperatures on the time scale of seconds, allowing for the fully automated rapid analysis of air samples by GC-MS. This sample trap is incorporated in a new analytical instrument, herein referred to as ACCBAR (Advanced Cryo-mechanical Chromatograph for BiosphericAtmospheric Research), which is capable of separating and quantifying a wide suite of C2-C10 VOCs with a 20 min cycle time and part-per-trillion-by-volume (pptv) sensitivity.

Sample collection of whole air samples by canisters extends the utility of GC-MS analysis to locations and platforms unsuitable for a ground-based detection system or where fast time resolution sampling on the order of seconds is required without loss of method sensitivities (McClenny et al., 1991; Wang and Austin, 2006). Electropolished stainless steel canisters have been used for many years for quantifying trace gases, including from aircraft platforms (Colman et al., 2001; Heidt et al., 1989; McClenny et al., 1996; Simpson et al., 2010, 2014). Due to the space and weight constraints of operating a whole air sampling system aboard research aircraft, this laboratory, in conjunction with the National Center for Atmospheric Research (NCAR), constructed a new semito fully automated system, the improved whole air sampler (iWAS), for field work (Warneke et al., 2016). This system packages 12 electropolished stainless steel canisters in rackmountable modules that can be rapidly installed in or uninstalled from a wing pod of the aircraft in sets of six and filled remotely. The sampler design and post-fabrication conditioning protocols have been adopted from the NCAR Advanced Whole Air Sampler (AWAS) and earlier whole air sampler designs (Heidt et al., 1989; Schauffler et al., 1999) and the UC Irvine whole air sampling program (Blake et al., 1994; Simpson et al., 2010). The NCAR AWAS system had previously been deployed for the NOAA field campaigns TexAQS II and CalNEX in 2006 and 2010, respectively (Parrish et al., 2009; Warneke et al., 2012). The stability of various classes of compounds in electropolished stainless steel canister systems as a function of canister preparation and sampling and analysis protocols has been well documented in the literature (Kelly and Holdren, 1995; Ochiai et al., 2002).

The combined iWAS/ACCBAR system was deployed during two aircraft-based field campaigns (summarized in Table 1). In summer 2013, the Southeast Nexus (SENEX) field campaign was conducted to investigate the roles of anthropogenic and biogenic emissions upon the formation of tropospheric ozone and secondary aerosol in the southeastern United States (Warneke et al., 2016). Twenty research flights were conducted aboard the NOAA WP-3D aircraft, based in Smyrna, TN, from May to July 2013. During SENEX, over 1100 canister samples were collected and subsequently analyzed in the field, with mixing ratios for 24 species reported. In spring 2015, the Shale Oil and Natural Gas Nexus (SONGNEX) field campaign was conducted to quantify the emissions of trace gases and fine particles from oil and natural gas basins throughout the western United States. The 
Table 1. Summary of measurement parameters for SENEX 2013 and SONGNEX 2015 campaigns.

\begin{tabular}{|c|c|c|}
\hline Parameter & SENEX 2013 & SONGNEX 2015 \\
\hline Field work dates & May-June 2013 & March-April 2015 \\
\hline Location of field work & Southeastern USA & Central/western USA \\
\hline Canisters analyzed & 1115 & 1326 \\
\hline Median time between collection and analysis (h) & 89 & 62 \\
\hline Canister humidification method & Humidified $\mathrm{N}_{2}$ & Water vapor \\
\hline Chromatogram analysis method & Manual integration & Semiautomated \\
\hline Species reported as of publication & 24 & 24 \\
\hline \multicolumn{3}{|l|}{ Expected ambient halocarbon mixing ratio (pptv) } \\
\hline $\mathrm{CF}_{2} \mathrm{Cl}_{2}$ & 523 & 518 \\
\hline $\mathrm{CFCl}_{3}$ & not used & 234 \\
\hline CFC-113 & not used & 73.8 \\
\hline $\mathrm{CCl}_{4}$ & 85.4 & 84.1 \\
\hline
\end{tabular}

NOAA WP-3D aircraft was based in Broomfield, CO, and Austin, TX, from March to May and conducted 19 research flights. Over 1300 canister samples were collected and analyzed, with 24 VOC species reported.

This paper presents the instrumental details for the iWAS sampling and ACCBAR GC-MS analysis systems, as well as the methods used to fill and sample the canisters and the postanalysis cleaning process. The data analysis workflow, including peak area integration, normalization and calibration, is detailed, as well as a description of a series of instrument tests to identify possible artifacts in either the sample collection or analysis systems. Finally, a comparison of a subset of final reported mixing ratios from two field campaigns with measurements made by other instruments is provided.

\section{Instrumental}

\subsection{Airborne whole air sample collection}

Air samples were collected aboard the NOAA WP-3D aircraft, with the sampling system installed in a wing pod mounted underneath the starboard wing of the aircraft. The sample train consists of an unheated forward-facing stainless steel inlet (10.2 mm ID) extending $15 \mathrm{~cm}$ from the outboard surface of the wing pod with a reduced diameter outlet $(2.2 \mathrm{~mm} \mathrm{ID})$ to increase ram air pressure and an orthogonal stainless steel sampling arm (10.2 mm ID). The sampling arm is connected via flexible stainless steel hose (9.5 mm ID) to a two-stage stainless steel bellows compressor (Senior Aerospace $\mathrm{p} / \mathrm{n} 28823-11$ ) used in series, capable of $>50 \mathrm{slpm}$ of air flow at $60 \mathrm{psia}(4140 \mathrm{hPa})$ with the inlet at $25^{\circ} \mathrm{C}$ and $14.7 \mathrm{psia}$. The $28823-11$ compressor is a modified version of the "off-the-shelf" 28823-7 model available from Senior Aerospace. The modifications are a fully sealed stainless steel bellows (no pressure relief pinholes) and the replacement of the pressure relief valve on the pump face- plate with a $1 / 8 \mathrm{in}$. NPT-tapped hole that is subsequently plugged with a stainless steel fitting. The modified stainless steel bellows is leak-tested with He to $1 \times 10^{-6} \mathrm{cc} \mathrm{s}^{-1}$ by the manufacturer prior to assembly, and all wetted surfaces are cleaned with methanol/ethanol. The compressor output is connected in series to six canister modules via welded manifolds of $4.6 \mathrm{~mm}$ ID electropolished stainless steel tubing with breakable connections made between the canister modules with Swagelok stainless steel metal gasket fittings (VCR) with silver-plated nickel gaskets. Each canister module holds $121.4 \mathrm{~L}$ electropolished stainless steel canisters that are isolated from the sampling manifold via pneumatically actuated stainless steel bellows valves (Swagelok $\mathrm{p} / \mathrm{n}$ SS-BN4VCR-C). The canister modules were built by UC Irvine and NCAR's Design and Fabrication Services. After the canister modules, the sample flow is exhausted through a proportional relief valve set at 60 psia, with a bypass port that opens to ambient pressure via a bellows valve. With the compressor operating, air flows through the sample manifold regardless of whether the valve to the bypass port is open.

Sample collection is controlled via a custom-built PC-104 data system (Diamond Systems, Mountain View, CA) running LabView-based software (National Instruments, Austin, TX) in a Microsoft Windows environment. The flight scientist communicates with the data system over the aircraft local area network using Windows remote desktop protocol. After takeoff, the compressor is started with the bypass port open to reduce back pressure. When the aircraft has reached the sampling area, the bypass port is closed to allow adequate manifold pressure for filling canisters. Air samples are sequentially collected by actuating the stainless steel bellows valve on an individual canister and allowing the canister to be pressurized to $50 \mathrm{psia}(3450 \mathrm{hPa})$. Fill time for a canister with the system at standard sea level pressure is $3 \mathrm{~s}$ and the time increases with increasing aircraft altitude (decreasing ambient pressure). At an altitude of 5000 ma.s.l. (meters above 


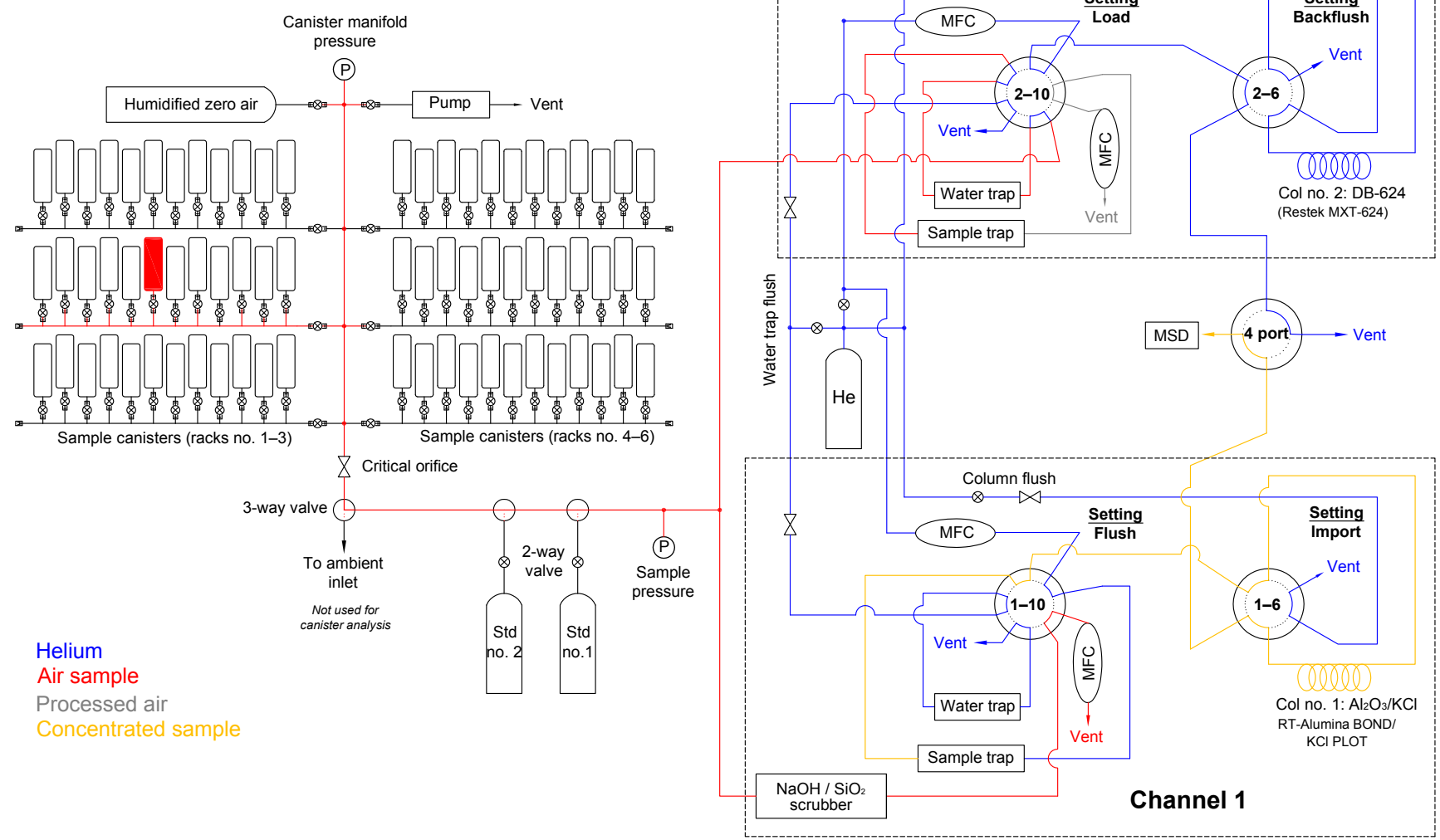

Figure 1. Schematic of instrument with flow path and valve position. Figure shown with open valve for a canister of middle-left sample module, Ch 1 flushing sample trap effluent to separation column, and Ch 2 loading sample trap.

sea level), fill time is typically $11 \mathrm{~s}$, and the maximum fill time allowed by the flight computer is $15 \mathrm{~s}$ regardless of fill pressure. During SONGNEX 2015, $\approx 95 \%$ of samples were collected below $3500 \mathrm{~m}$ a.s.l. and had fill times between 3 and $7 \mathrm{~s}$. At typical air speeds of $100 \mathrm{~m} \mathrm{~s}^{-1}$, these samples average the VOC composition over $<1 \mathrm{~km}$ of the flight track. The data system can be operated in a survey mode, whereby canisters are automatically filled at set intervals (typically 180 to $450 \mathrm{~s}$ between samples). The flight scientist is also able to immediately collect sample(s) with an override function and can adjust the sample interval as required. Canister fill times are transmitted to the onboard flight scientist over the aircraft local area network and to scientists on the ground along with the aircraft GPS coordinates allowing for real-time mapping of sampling. When all canisters have filled, the sample manifold bypass valve is opened for venting and the compressor is turned off.

\subsection{Post-flight analysis via GC-MS}

\subsubsection{Sampling from the canisters}

Each canister is sequentially analyzed post-flight in the field with ACCBAR (Fig. 1). The canister modules are connected to a welded electropolished stainless steel sampling manifold via $2.2 \mathrm{~mm}$ ID passivated stainless steel tubing (Restek Sulfinert-treated). The sampling manifold has eight electropolished stainless steel bellows valves, which isolate individual canister modules as well as a two-stage diaphragm vacuum pump and a supply of zero air (General Air, ultrazero grade) humidified by bubbler containing water (Sigma Aldrich, HPLC grade). The sample manifold is connected to the GC-MS with a VCR fitting using a nickel-plated stainless steel gasket with a $100 \mu \mathrm{m}$ orifice, and the remaining flow path to the GC-MS consists of $2.2 \mathrm{~mm}$ ID passivated stainless steel; the total internal volume of the sample manifold is approximately $80 \mathrm{~cm}^{3}$. Once all six canister modules are installed, the entire sample train is evacuated to $<0.01$ psia to remove any residual liquid water in the canister module manifolds and to check for leaks. Once analysis begins, the sample manifold and target canister module manifold are evacuated to $<0.002 \mathrm{psia}$, then filled with humidified zero air to $>30$ psia and evacuated again before each sample. The sample analysis system is also tested for artifacts by analyzing the humidified zero air flush gas, typically before running canisters and after each set of 24 canisters has been analyzed. The target canister is opened $6 \mathrm{~s}$ before the GC-MS sampling 
valve is activated, allowing the sampling manifold to reach sufficient pressure to deliver sample flow $(120 \mathrm{sccm})$ to the instrument through the orifice and to passivate the manifold surfaces with each sample prior to analysis. The GC-MS control system evaluates the sample manifold pressure one second before opening the sample valve; if the manifold pressure is below 30 psia the GC-MS will automatically switch to an instrument zero to avoid sampling a vacuum (see below). This condition is typically met as a result of a canister that failed to fill during flight. If the manifold pressure is greater than 30 psia, the system will continue to flush the manifold and GC sample inlet for $35 \mathrm{~s}$ before sample acquisition is initiated.

\subsubsection{Sample analysis and description of GC-MS}

Conceptually, ACCBAR is a series of traps used to reduce unwanted component(s) from the air sample matrix (i.e., water and carbon dioxide) while concentrating the target analytes, which are subsequently injected on separation columns and detected via mass spectrometry on a $20 \mathrm{~min}$ cycle. The custom-built GC-MS ACCBAR consists of two channels, with channel 1 optimized for C2-C6 hydrocarbons and halocarbons using a PLOT column and channel 2 optimized for C6-C10 hydrocarbons and oxygen- and nitrogen-containing species using a low- to mid-polarity phase column. A single quadrupole mass spectrometer detector (MSD) runs in selective ion mode for increased signalto-noise response and sequentially analyzes the effluent from the two columns. This instrument is based on a two-channel GC-MS developed by NOAA Chemical Sciences Division and deployed on many field campaigns over the past 15 years (Gilman et al., 2013; Goldan et al., 1995). The new instrument is designed for field deployment, capable of measuring in situ or analyzing canister samples, and is built into a $104 \mathrm{~cm} \times 104 \mathrm{~cm} \times 64 \mathrm{~cm}(\mathrm{H} \times \mathrm{W} \times \mathrm{D})$ rack shock-mounted on casters. ACCBAR requires no cryogen (e.g., liquid nitrogen), consuming only carrier gas (ultra-high purity $\mathrm{He}$ ), calibration gases (typically zero air and a secondary standard, discussed below) and 120 VAC power $(2 \times 15$ A circuits $)$. The new GC-MS was successfully deployed in 2013 for SENEX to the Smyrna/Rutherford County Airport (Smyrna, $\mathrm{TN})$ via a towable laboratory trailer which was parked inside an aircraft hangar; for SONGNEX in 2015, ACCBAR remained in the CSD laboratory since field operations were predominantly from the nearby Rocky Mountain Metropolitan Airport (Broomfield, CO).

Figure 1 presents a schematic of the flow path of ACCBAR, along with alternative settings of the five twoposition chromatography valves (Valco, Vici Instruments, Houston, TX) used to direct gas flow. Channel 1 is shown with the 10-port valve (1-10) in "flush" mode and the 6-port valve (1-6) in "import" mode, where the sample trap is connected to the separation column with carrier gas (UHP He) flowing through the sample trap and to the column. Channel (a)
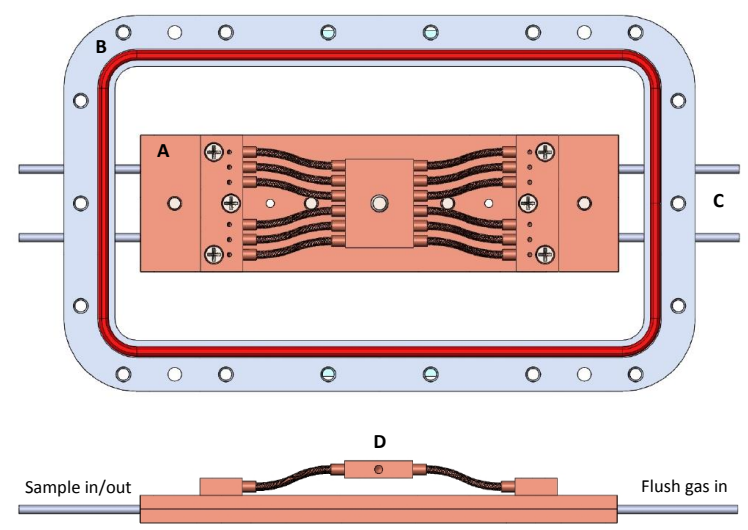

(b)

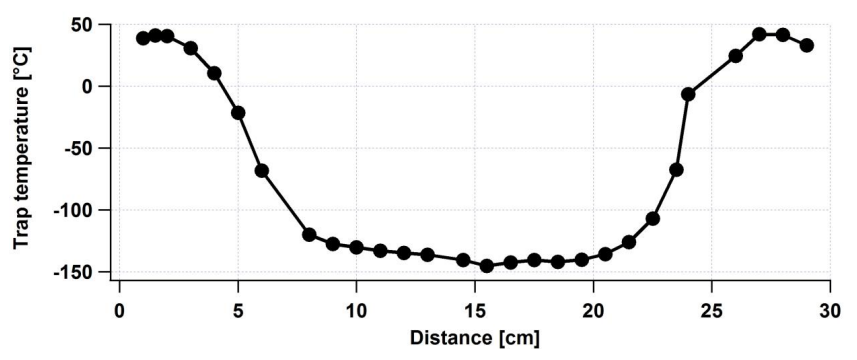

Figure 2. (a) Drawing of ACCBAR sample trap (top view, side view). The cold block (A) is mounted inside a vacuum chamber (B), suspended upon two $3.2 \mathrm{~mm}$ OD stainless steel tubes (C). The Stirling cooler cold finger (not shown) bolts to the floating stage (D) centered above the cold block. (b) Temperature profile of Ch no. 2 sample trap at nominal $-135^{\circ} \mathrm{C}$.

2 is shown with the 10-port valve (2-10) in "load" mode and the 6-port valve (2-6) in "backflush" mode, where sample flow is directed through a water trap followed by the sample trap, while the separation column is isolated and backflushed with UHP He. The four-port valve is shown directing channel flow from the separation column on channel 1 to the mass spectrometer, while channel 2 flow (UHP He) is vented. All chromatography valves have stainless steel bodies with polyaryletherketone/PTFE rotors with $0.40 \mathrm{~mm}$ diameter channel, without external purging. The valves and transfer lines (Restek, 1/16 in. OD Sulfinert-treated stainless steel) are housed within an oven that is held at a constant $80{ }^{\circ} \mathrm{C}$.

When performing analysis, two $240 \mathrm{~cm}^{3}$ (standard pressure and temperature) air aliquots are simultaneously collected from each canister to both channels over 4 min at a flow rate of $60 \mathrm{sccm}$ controlled by individual mass flow controllers (Pneucleus MicroFlo, Hollis, NH). There is no vacuum pump downstream of the flow controllers which vent to ambient, so positive pressure is required upstream of the GC-MS sample inlet. If the inlet pressure is sub-ambient it is possible that flow will reverse in the sample path, so this 
condition must be avoided. Carbon dioxide $\left(\mathrm{CO}_{2}\right)$, which can freeze and plug the channel 1 sample trap at collection temperature, must be removed. The channel 1 sample passes through a bed of heated $\left(35^{\circ} \mathrm{C}\right)$ granular $\mathrm{NaOH}$-coated silica (Ascarite II) packed in a $10 \mathrm{~cm}$ PFA tube $(6.3 \mathrm{~mm}$ ID) with silanized borosilicate wool at each end (Goldan et al., 2004). No $\mathrm{CO}_{2}$ trap is required for channel 2 , as the sample trap temperature is just warm enough to prevent freezing of $\mathrm{CO}_{2}$ at the residence time of the trap. Water vapor also must be removed from the air samples to prevent ice buildup in the subsequent sample traps, which would cause plugged flow, as well as to prevent degradation of the PLOT column used for channel 1. Prior to sample trapping, the air aliquot for each channel passes through a water trap, which is a $36 \mathrm{~cm}$ loop of $2.0 \mathrm{~mm}$ ID PEEK tubing inside a coaxial stainless steel tube resistively heated to control temperature, mounted in an insulated aluminum cold block. The water traps are cooled to $-20^{\circ} \mathrm{C}$ during trapping and then are heated to $100^{\circ} \mathrm{C}$ for 12.9 min between sample injections while being backflushed with UHP He. The water trap cold block is chilled with a single-stage mechanical refrigerator (Neslab, model CC-65) during operation. The water traps are able to cool from purge to trapping temperature in approximately $45 \mathrm{~s}$ and are controlled within $0.2^{\circ} \mathrm{C}$ of set point during trapping.

After passing through the water traps, analytes from the air samples are pre-concentrated via cryogenic trapping at nominal temperatures of -165 and $-135^{\circ} \mathrm{C}$ for channels 1 and 2, respectively. The sample traps (Fig. 2a) are a novel design, using a Stirling cooler (Sunpower Inc., Athens, OH, model CryoTel GT) to achieve trapping temperatures without the need for liquid nitrogen. The CryoTel GT cooler is capable of $16 \mathrm{~W}$ lift capacity (e.g., heat removal) at $-196^{\circ} \mathrm{C}$ at maximum power (240W input) while weighing only $3.1 \mathrm{~kg}$. The cold end of the cooler terminates in a threaded cold finger, which is bolted to a small copper plate $(25 \mathrm{~mm} \times 25 \mathrm{~mm} \times 6 \mathrm{~mm})$ that is attached to a larger copper cold block $(178 \mathrm{~mm} \times 51 \mathrm{~mm} \times 10 \mathrm{~mm})$ via 12 stranded copper wires (10 AWG). This serves to mechanically isolate the cold finger from the cold block while still allowing efficient thermal transfer. The copper cold block is mounted in a $20 \mathrm{~cm} \mathrm{ID} \times 6.2 \mathrm{~cm}$ cylindrical vacuum chamber, suspended by two $3.2 \mathrm{~mm}$ OD, $2.7 \mathrm{~mm}$ ID stainless steel tubes that are sealed with Swagelok Ultra-Torr fittings. The Stirling cooler is mounted to the top of the chamber via a KF-50 vacuum flange attached to the cooler at the terminus end of the cold finger, and a turbomolecular pump is mounted to the bottom of the chamber to reduce pressure inside the chamber below $1 \times 10^{-4} \mathrm{hPa}$. The vacuum chamber has additional ports to allow for pressure measurement and sensor and heater wiring to the cold block.

The sample traps consist of a $330 \mathrm{~mm}$ section of treated fused silica tubing $(0.53 \mathrm{~mm}$ ID) mounted inside a thin-wall hypodermic stainless steel tube $(0.97 \mathrm{~mm} \mathrm{ID}, 1.08 \mathrm{~mm} \mathrm{OD})$ that is resistively heated. The treated fused silica tubing used for channel 1 is $\mathrm{Al}_{2} \mathrm{O}_{3} / \mathrm{KCl}$ PLOT column (Restek RT-
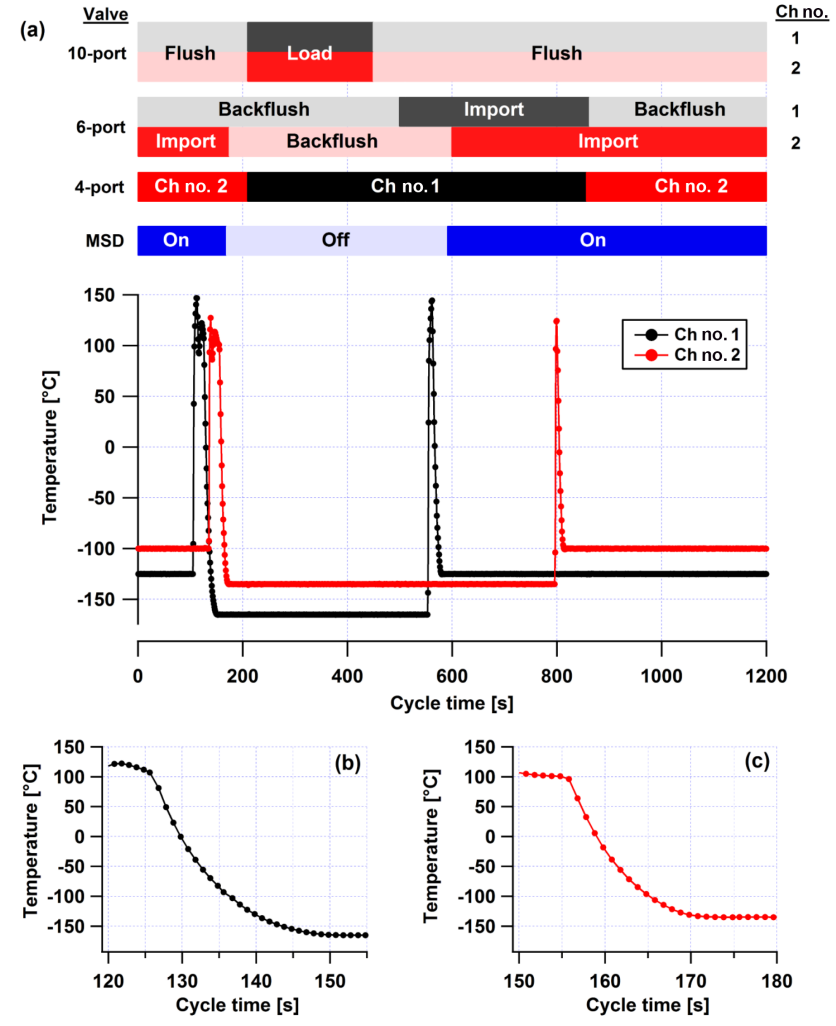

Figure 3. (a) Valve positions and temperature profile of sample traps for an analysis cycle. The 10-port valves control flow to the water and sample traps, the 6-port valves control flow to the separation columns and the 4-port valve controls flow to the detector. (b) For Ch no. 1 trap, the exponential rate of cooling $\approx 8.4 \mathrm{~s}$ and the trap is cooled from 100 to $-165^{\circ} \mathrm{C}$ in $25 \mathrm{~s}$. (c) For Ch no. 2 trap, the exponential rate of cooling $\approx 7.0 \mathrm{~s}$ and the trap is cooled from 100 to $-135^{\circ} \mathrm{C}$ in $18 \mathrm{~s}$.

Alumina $\mathrm{BOND} / \mathrm{KCl}$ ), with the $\mathrm{Al}_{2} \mathrm{O}_{3}$ scraped from each end of the tubing so that only the center $180 \mathrm{~mm}$ is coated; channel 2 uses deactivated fused silica (Restek Rxi Guard) without modification. To allow temperature control of the sample trap, a type-T thermocouple is adhered to the outer wall of the hypodermic tubing with shrink tubing, which electrically isolates the heater from the outer support tubing. The ends of the hypodermic tubing - that part of the heater tubing that is not positioned inside the cold block - are plated with $30 \mu \mathrm{m}$ copper then flashed with gold to reduce the resistance of the heaters at the ends; this avoids overheating the ends of the sample trap while controlling the temperature in the center (Fig. 2b). The trap assemblies are installed inside the $3.2 \mathrm{~mm}$ OD stainless steel support tubes described above. During typical operation throughout the sample cycle, the Stirling cooler is operated at $220 \mathrm{~W}$ rather than full power, as this is adequate to maintain an average cold block temperature of $-180^{\circ} \mathrm{C}$. At maximum cooler power, it is possible to operate the sample traps at temperatures as low as $-200^{\circ} \mathrm{C}$. 


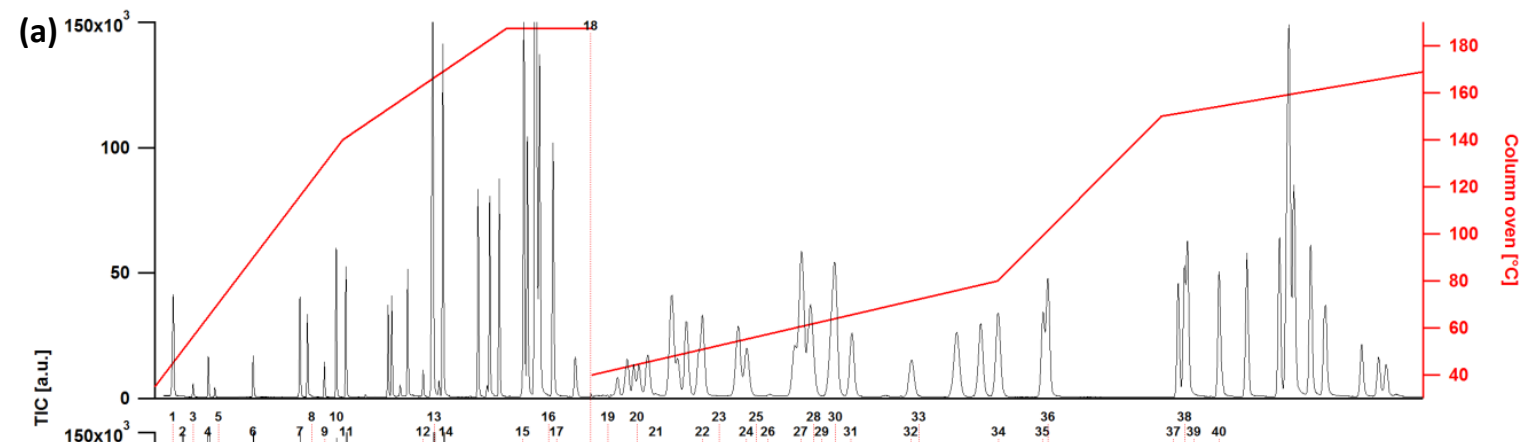

(b)

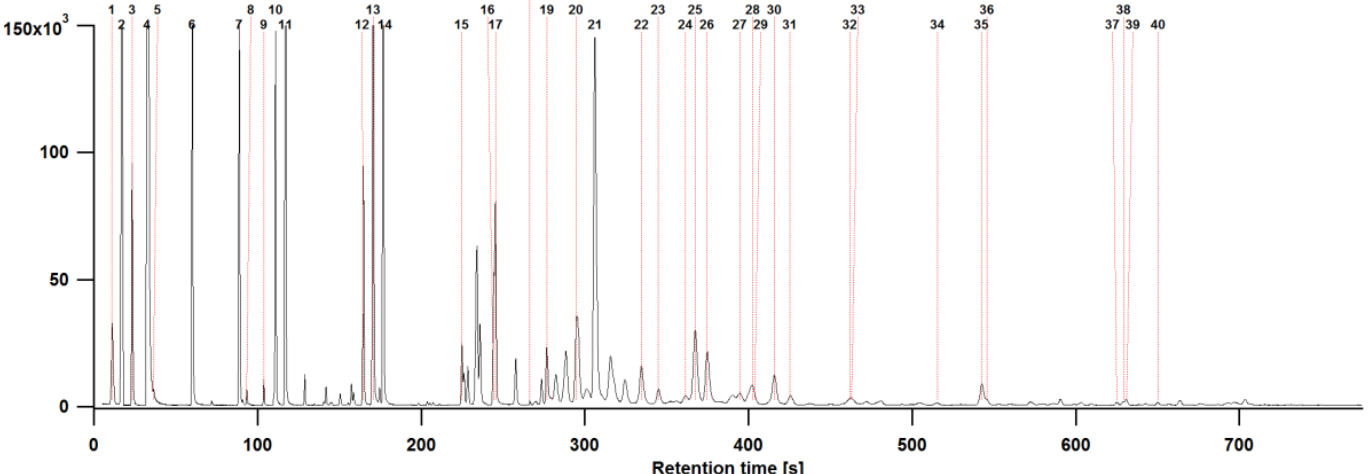

$\begin{array}{ll}1 \text { Air spike } & 9 \text { Ethyne } \\ 2 \text { Xenon } & 10 \text { Butane, iso- } \\ 3 \text { Ethane } & 11 \text { Butane, } n- \\ 4 \text { Nitrous oxide } & \mathbf{1 2} \text { Freon-11 }\left(\mathbf{C F C l}_{3}\right) \\ 5 \text { Ethene } & 13 \text { Pentane, iso- } \\ 6 \text { Propane } & 14 \text { Pentane, } n- \\ 7 \text { Freon-12 }\left(\mathbf{C F}_{2} \mathrm{Cl}_{2}\right) & \mathbf{1 5} \text { CFC-113 }\left(\mathbf{C F C l}_{2}-\mathbf{C F}_{2} \mathbf{C l}\right) \\ 8 \text { Propene } & 16 \text { Hexane, n- }\end{array}$

17 Isoprene
18 Start of channel 2
19 Methanol
20 Ethanol
21 Acetone
22 Hexane, n-
23 Methacrolein
24 Cyclopentane, methyl-

25 Methyl vinyl ketone

33 Nitrate, i-propyl-

26 Methyl ethyl ketone

27 Cyclohexane

Nitrate, n-propyl-

28 Carbon tetrachloride

29 Nitrate, ethyl-

30 Benzene

31 Heptane, $n$ -

32 Cyclohexane, methyl-

35 Toluene

36 Octane, $n$ -

37 Benzene, ethyl-

38 Nonane, $n$ -

39 Xylenes, $\mathrm{m} \& \mathrm{p}$ -

40 Xylene, o-

Figure 4. Chromatograms displayed as total ion current (TIC) with select peaks identified. Top panel (a) shows secondary standard, along with temperature ramp for each GC channel. Bottom panel (b) shows air sample collected in the Haynesville oil and gas field near Shreveport, Louisiana, 25 April 2015.

Fig. 3a shows a typical temperature trace for each sample trap during an analytical cycle. At cycle time $(t)=0 \mathrm{~s}$, the traps are held at temperatures slightly above trapping temperatures $\left(-120\right.$ and $-100^{\circ} \mathrm{C}$ for channel 1 and 2, respectively) while being backflushed with UHP He to reduce the heat load to the Stirling cooler between sampling periods. Before sample trapping begins, both traps are heated sequentially to $>100^{\circ} \mathrm{C}$ (at $t=105$ and $t=135 \mathrm{~s}$ for channels 1 and 2, respectively) and held at this temperature for $20 \mathrm{~s}$ to ensure the traps are as clean as possible, then cooled to their trapping temperatures $\left(-165\right.$ and $-135^{\circ} \mathrm{C}$ for channel 1 and 2 , respectively). The heater design allows for rapid heating and cooling of the sample traps, so the traps can switch from cold to hot set point temperatures in less than $3 \mathrm{~s}$ and can be cooled from $100^{\circ} \mathrm{C}$ to their respective trapping temperatures in less than $30 \mathrm{~s}$ (Fig. $3 \mathrm{~b}$ and c). The novel geometry of the sample trap and the duty cycles of the heaters allows for this performance, while operating within the constraints of the lifting power of the Stirling cooler.

Sample flow is directed to both traps starting at $t=210 \mathrm{~s}$ by switching the 10-port valves from "flush" to "load" position which is maintained for $240 \mathrm{~s}$ at a flow rate of $60 \mathrm{sccm}$; during sample collection, the sample trap temperature is controlled to within $0.2{ }^{\circ} \mathrm{C}$ by heating. At $t=450 \mathrm{~s}$, the 10 -port valves simultaneously switch back to the "flush" position stopping sample flow to the traps, which are then backflushed with UHP He while maintaining trapping temperatures. This post-collection flush removes most of the untrapped permanent gases (e.g., nitrogen, oxygen, argon) from the sample trap flow path, thereby reducing the chromatogram background signal at the start of each channel. The sample traps are flash-heated at $t=553$ and $t=796 \mathrm{~s}$ of the cycle (channel 1 and 2 , respectively) to $100^{\circ} \mathrm{C}$ to inject the analyte onto the separation columns. The trapped volume is small enough 
and is injected onto the column quickly/efficiently enough so that no cryofocus is required on the column heads.

After trapping, the concentrated samples are injected in turn onto the respective chromatography columns. UHP He is used as the carrier gas, at a constant flow of $2 \mathrm{sccm}$, with the total chromatogram requiring $780 \mathrm{~s}$ of run time. After separation, the column effluent is directed sequentially to the MSD via a four-port valve (Fig. 1), with channel 1 measured first, followed by channel 2. Channel 1 uses an $\mathrm{Al}_{2} \mathrm{O}_{3} / \mathrm{KCl}$ PLOT column (Restek RT-Alumina BOND/KCl; $30 \mathrm{~m}$ length, $0.25 \mathrm{~mm}$ ID, $4 \mu \mathrm{m}$ film thickness), with a temperature profile ramped from 35 to $190^{\circ} \mathrm{C}$ in $190 \mathrm{~s}$. Channel 2 uses a lowto mid-polarity modified methylpolysiloxane (Restek MXT624; $30 \mathrm{~m}$ length, $0.25 \mathrm{~mm} \mathrm{ID,} 1.4 \mu \mathrm{m}$ film thickness), with a temperature profile ramped from 40 to $170^{\circ} \mathrm{C}$ in $518 \mathrm{~s}$. For both columns, the temperature programs are multi-step ramps with several different heating rates used to optimize peak separation for each column (Fig. 4a). The columns are individually sheathed inside two custom interlocking aluminum spindles $(12.2 \mathrm{~cm}$ OD, $10.5 \mathrm{~cm}$ ID). The columns are wrapped around the innermost spindle along with resistive temperature detectors (RTDs) for temperature measurement. The spindles are heated resistively with Kapton thinfilm heaters. Both spindles are suspended inside fiberglass housings by thin $(0.38 \mathrm{~mm})$ stainless steel tabs. The housings have $150 \times 172 \mathrm{~mm}$ fans mounted on one side to cool the columns; the fans are operated by pulse-wave modulation and can be reduced to $\approx 40 \%$ power, allowing for low air flow rates across the heated column spindles and thereby improving temperature control at temperatures close to ambient. After each column has completed separation, it is backflushed with UHP He while heated to 190 or $210^{\circ} \mathrm{C}$ for channel 1 and 2, respectively, before cooling in preparation for the next sample.

The mass spectrometer (Agilent model 5975C) is usually operated in selected ion monitoring mode, scanning up to 11 masses per window, 28 windows per chromatogram with dwell times between 10 and $20 \mathrm{~ms}$ per mass, to optimize instrument sensitivity while providing enough sample points per mass to accurately determine peak area. Beginning with the 2015 SONGNEX campaign, a new peak-integration software package called TERN (Aerodyne Research, Inc.) has been used for automated peak-area retrieval (IsaacmanVanWertz et al., 2017). TERN is a custom-designed chromatographic data handler and peak integration package built upon Igor Pro's (Wavemetrics, Inc.) multi-peak fitting functionality. Chromatographic peaks are fit by minimizing the residual of a set of Gaussian and exponentially modified Gaussian peaks for a subset of the chromatogram (typically $20 \mathrm{~s}$ ) on a single mass. The peak within this optimized fit considered most likely to be the analyte of interest is returned, and the peak area is calculated from the coefficients of the solution. Use of TERN to integrate chromatograms has reduced analysis time to approximately $1.25 \mathrm{~min}$ per chromatogram, at least an order of magnitude faster than the previous method using Agilent ChemStation and hand integration, while increasing peak area precision and accuracy (Isaacman-VanWertz et al., 2017). Additional information about TERN's peak fitting method and an intercomparison between peak areas determined by manual integration and automatic peak fitting is provided in the Supplement.

\subsubsection{Canister cleaning and conditioning}

After the canisters have been analyzed, they must be prepared and conditioned for reuse. An automated cleaning oven has been constructed that allows for the unattended processing of three canister modules at one time. All tubing and fittings in the oven are stainless steel. Each canister manifold, and then each individual canister, is evacuated and leak-tested. The canisters are then heated to $65^{\circ} \mathrm{C}$ under vacuum using a dry scroll pump for $1 \mathrm{~h}$, typically to less than $0.01 \mathrm{hPa}$ as measured between the canister modules and the pump. Canisters are then filled with humidified high-purity nitrogen gas (UHP $\mathrm{N}_{2}$ or liquid nitrogen blow-off) and re-evacuated. The nitrogen flush and pump out process is repeated a minimum of three times. After the final canister pump down, approximately $15 \mathrm{hPa}$ of water vapor is added to the canisters to reduce artifacts in the subsequent air sample collected in the canisters (Ochiai et al., 2002). Water for both nitrogen humidification and water vapor addition is HPLC-grade (Sigma-Aldrich), in a bubbler heated to nominally $35^{\circ} \mathrm{C}$. After the final evacuation step of the cleaning cycle, all sample canisters are opened for $2.5 \mathrm{~min}$ in order to be filled to $\sim 15 \mathrm{hPa}$ with water vapor. This is done by shutting off the nitrogen flow to the water bubbler so that only the headspace over the water reservoir is available to fill the evacuated canisters with water vapor. Water is delivered to the canisters via stainless steel tubing. The final fill pressure varied by less than $5 \%$ for each campaign. The cleaning and humidification procedure is based upon a survey of canister preparation methods presented in the literature (Colman et al., 2001; McClenny et al., 1991; Plass-Dülmer et al., 2006; WMO, 2012), albeit at a slightly lower bake-out temperature than the range cited $\left(70-80^{\circ} \mathrm{C}\right)$. After the SONGNEX field campaign, the cleaning oven was rebuilt to operate at $75^{\circ} \mathrm{C}$.

A full research flight of 72 canisters (6 modules) requires at least $12 \mathrm{~h}$ of cleaning and conditioning before they are ready to be reused. For the SENEX field campaign, humidified UHP nitrogen was used rather than water vapor, as most canisters were collected in the summertime southeastern US planetary boundary layer where ambient water vapor is adequate to condense liquid water in the sample canisters at sample pressures. This was switched to using water vapor for the SONGNEX campaign to ensure consistency of total water content in the canisters between the field campaigns. The presence of condensed water in the sample canisters is expected to have a deleterious impact upon soluble oxygenated VOCs (e.g., alcohols; Ochiai et al., 2002). Further discussion of water effects is presented in Sect. 3.4.4 below, and the am- 
bient water mixing ratios of the collected samples from each field campaign is described in the Supplement. During a field campaign, the efficacy of the cleaning system is evaluated by filling cleaned and humidified canisters with the same zero air gas used to test for artifacts (Sect. 3.4.2).

\section{Results: normalization, calibration, artifacts}

\subsection{Normalization of instrument response}

For both chromatograph channels, normalization is required to account for changes in instrument sensitivity primarily attributable to changes in detector response. Long-lived halocarbon species in the atmosphere are used for normalization, effectively serving as internal standards for canister samples (Karbiwnyk et al., 2003). Four halocarbons have been selected (only two were used for SENEX), which are abundant and relatively constant in tropospheric air as a function of latitude over the typical onemonth time period of a field campaign: Freon-12 $\left(\mathrm{CF}_{2} \mathrm{Cl}_{2}\right.$, dichlorodifluoromethane), Freon-11 $\left(\mathrm{CFCl}_{3}\right.$, trichlorofluoromethane), $\mathrm{CFC}-113\left(\mathrm{CFCl}_{2}-\mathrm{CF}_{2} \mathrm{Cl}, 1,1,2\right.$-trichloro-1,2,2trifluoroethane) and carbon tetrachloride $\left(\mathrm{CCl}_{4}\right.$, tetrachloromethane). Expected mixing ratios in ambient air for each halocarbon (Table 1) are estimated from data provided by the NOAA Global Monitoring Division using averaged monthly data from the nearest sampling sites by latitude: Niwot Ridge, CO, and Trinidad Head, CA (Montzka et al., 2015). These halocarbons are also added quantitatively to a custom dilution of a 57-component ozone precursor hydrocarbon standard (Scott Specialty Gases) in UHP nitrogen. The mixing ratio of the secondary standard is $275 \mathrm{pptv}$ for all hydrocarbons with $7 \%$ uncertainty for each compound. The secondary standard also contains the halocarbons used for normalization at the following mixing ratios with $6 \%$ uncertainty: $\mathrm{C}_{F} 2 \mathrm{Cl}_{2}=140, \mathrm{CFCl}_{3}=26.2, \mathrm{CFC}-113=12.0$ and $\mathrm{CCl}_{4}=87.5$ pptv. This gas mixture serves as a singlepoint secondary standard during field measurements to characterize instrument response throughout the campaign. The secondary standard is also measured periodically during sensitivity studies (Sect. 3.2), as the analyte consists of standard(s) diluted in UHP nitrogen and therefore has no significant halocarbon mixing ratios. This allows for quantification of normalization factors in both ambient samples and calibration samples. An example time series for the raw instrument response for a halocarbon and hydrocarbon species in the secondary standard measured on each channel is provided in the Supplement (Fig. S4).

A normalization factor is calculated for every sample, based on the raw peak area for $\mathrm{CF}_{2} \mathrm{Cl}_{2}$ on channel $1\left(\mathrm{CFCl}_{3}\right.$ and CFC-113 were also used for SONGNEX, see below), and $\mathrm{CCl}_{4}$ on channel 2 . The calculation of a normalization factor (NF) is shown in Eq. (1):

$\mathrm{NF}=$ Raw $_{\text {halo }} /$ Target $_{\text {halo }}$.
Here, halo is a halocarbon used for normalization, Raw is the integrated raw counts for a peak and Target is the expected raw counts. The secondary standard has a $\mathrm{CCl}_{4}$ mixing ratio of $87.5 \mathrm{pptv}$, with a target response of 15000 counts; during SONGNEX an ambient mixing ratio of $84.1 \mathrm{pptv}$ as reported by NOAA GMD, and a target response of 14400 counts was assumed. For SENEX, a single normalization factor was calculated for each channel using Eq. (1). For SONGNEX, three normalization factors $\left(\mathrm{NF}_{\text {halo }}\right)$ were calculated for channel 1 from halocarbon responses spanning that channel's elution time (Fig. 4). The final normalization factor was then calculated by linear interpolation, based upon the target analyte retention time (Eq. 2); for species eluting outside these halocarbon retention times, the nearest halocarbon factor was used.

$$
\begin{aligned}
\mathrm{NF}_{\mathrm{sp}} & =\mathrm{Raw}_{\mathrm{sp}} /\left[\mathrm{NF}_{\text {halo }_{2}}-\left(\mathrm{NF}_{\text {halo }_{2}}-\mathrm{NF}_{\text {halo }_{1}}\right)\right. \\
& \left.\times\left(\mathrm{RT}_{\text {halo }_{2}}-\mathrm{RT}_{\mathrm{sp}}\right) /\left(\mathrm{RT}_{\text {halo }_{2}}-\mathrm{RT}_{\text {halo }_{1}}\right)\right]
\end{aligned}
$$

Here, sp is the analyte species of interest, halo 1 and halo 2 are the halocarbons eluting before and after the analyte, respectively, and RT is retention time. The additional step of fitting multiple halocarbons was performed for channel 1 to account for some additional sensitivity changes independent of the detector response, which may be related to changes in trapping efficiency of the PLOT material in the sample trap. Peak areas are reported as normalized kilocounts (nkcts) simply by dividing the raw peak area by the relevant NF. This method is applied to all samples with known mixing ratios of these halocarbons, either from standards or ambient air, rather than interpolating only between standards in order to improve the accuracy of the normalization. For samples with no or unknown mixing ratios of halocarbons (e.g., instrument zeros, sensitivity calibrations), the normalization factors are interpolated from ambient and calibration samples.

\subsection{Calibration}

Sensitivities for all reported species are individually calculated by measuring the instrument response to a set of dynamic dilutions of gravimetric standards, using humidified UHP nitrogen as the diluent. Dilutions are made using a dynamic dilution system, consisting of two high flow mass flow controllers to provide UHP $\mathrm{N}_{2}$ flow both through and bypassing a glass bubbler filled with HPLC water (Sigma Aldrich), and a low flow MFC or crimped stainless steel capillary tube to provide standard gas to the system. The low flow MFC is used only for hydrocarbon standards (e.g., PAMS 57 component mix) as oxygenated gas standards through MFCs have resulted in the observation of unstable peak areas that are resolved by using crimped capillaries at controlled temperature. The high flow MFCs are controlled to provide total dilution flow between 0.5 and 10 slpm while allowing humidity to be varied between 0 and $80 \%$ relative humidity (RH). For system calibrations, the RH is typically held between 35 
and $40 \%$ for all data points. The analyte flow is controlled at multiple setpoints between 0.3 and $3 \mathrm{sccm}$ with the low flow MFC, while crimped capillaries allow constant flow within the same range. Flows are measured using DryCal flow meters for dilution flows and a soap bubble flow meter for analyte flows. All tubing used in the dynamic dilution system is $6.2 \mathrm{~mm}$ OD PFA, and a $10 \mathrm{~m}$ loop of PFA tubing is placed between the dilution system and instrument to ensure adequate mixing before sampling.

Typically, at least seven dilution levels are sampled over at least 3 orders of magnitude; for SONGNEX, this range was 0.03-70 ppbv. Hydrocarbon calibrations are performed with a nominal $1 \mathrm{ppm}$ PAMS 57-component commercial standard (Scott Specialty), with a stated $5 \%$ uncertainty of individual component concentrations. Other species - oxygenated compounds, alkyl nitrates, monoterpenes - are calibrated with in-house-made gravimetric standards consisting of 1-10 ppm mixtures of up to 10 species, with $5 \%$ uncertainties. In-house standards include at least two hydrocarbons also found in the PAMS standard, typically benzene or toluene, in order to confirm that instrument response is consistent across a series of calibration tests. Secondary gas standards are exchanged and analyzed with the NOAA Global Monitoring Division (GMD) Halocarbons and other Atmospheric Trace Species (HATS) group on an informal basis every 1 to 2 years to establish the veracity of the stated gas standard concentrations. This process led to the discovery of the misstated ethane mixing ratio in our current primary PAMS standard (14\% higher than stated). Accounting for additional measurement errors of flows of the dynamic dilution system, $1 \%$ for analyte and $2 \%$ for dilution, we define the calibration accuracy as the uncertainties of concentration and flow added in quadrature. These values are listed in Table 2. We have left the larger uncertainty in ethane accuracy in our current description of the GC-MS performance, as we are continuing to evaluate ethane standards.

Instrument responses for most compounds are nonlinear over the dynamic range of the calibrations. This behavior is consistent with what has been observed on this laboratory's previous GC-MS system, although the nonlinear response on the previous generation of this instrument was only significant for later eluting compounds (those after benzene). When plotted with linear-log scaling, the behavior is sigmoidal, in that sensitivity is constant at low mixing ratios, then transitions to a higher sensitivity at high mixing ratios. The sensitivity can be described well with an exponential function:

Sens $=\operatorname{Sens}_{0}+A / e^{\left(\frac{\tau}{\mathrm{nct}}\right)}$,

where Sens is the sensitivity at a given normalized count signal (nct), Sens 0 is the sensitivity at low mixing ratios, A is the difference in sensitivity between low and high mixing ratios and $\tau$ is the normalized count signal midway between low and high sensitivity. An example of solving for the nonlinear sensitivity (for $\mathrm{m}, \mathrm{p}$-xylenes) is presented in
Fig. 5, where a seven-point calibration curve is shown spanning $0.025-1.0 \mathrm{ppbv}$ mixing ratio. The linear fit statistics for the data points indicate a very good fit (Fig. 5a), with a small uncertainty of the slope $(<2 \%)$ and $r^{2}=0.999$. However, replotting the data on a log-log scale (Fig. 5b) shows that the fit does a poor job describing the data collected at the lowest mixing ratios. Solving for individual sensitivities at each calibration mixing ratio, simply by dividing normalized counts by mixing ratio and plotting versus normalized counts on a logarithmic, shows the sigmoidal behavior described above (Fig. 5c). These data are described well with Eq. (3), and comparing calculated mixing ratios found with the linear and nonlinear sensitivities (Fig. 5d) shows that the nonlinear sensitivity provides an excellent match across the entire dynamic range of the calibration. We also provide a measure for the nonlinearity, using the ratio of $\mathrm{A}: \mathrm{Sens}_{0}$, for all species reported in Table 2; for the earliest eluting compounds no nonlinearity is observed.

This behavior is the opposite of what is typically observed when analyte breakthrough occurs at the sample trap, and we have tested the instrument up to $180 \mathrm{ppbv}$ with a mixture of light hydrocarbons most susceptible to breakthrough (ethane, ethene, propane, propene, ethyne, n-butane) with no observed decrease in sensitivity; this mixing ratio is larger than any we have observed in ambient air with the WAS system. The nonlinearity is currently attributed to the water trap. At high mixing ratios the gas-phase analyte reaches equilibrium with adsorbed analyte on the wetted surfaces of the water trap, while at low mixing ratios this equilibrium is never reached and losses are kinetically determined. Precise control of the water trap temperature and sample flow rate are required to ensure that the nonlinearity is reproducible. Alternative water trap geometries and materials are currently under investigation to reduce this nonlinearity.

\subsection{Precision, limits of detection and total analysis uncertainty}

Instrumental precision for most species is determined from the measurement of the secondary standard described in Sect. 3.1 during field measurements. The secondary standard is typically measured at the beginning and end of each flight analysis and at least three times during analysis. For example, during SONGNEX 1327 sample measurements and 138 standard measurements were made. Precision is defined here as relative deviation from the mean of the normalized response for each species measured in the secondary standard, reported as a percentage. For species that are not in the standard, precision is estimated from the standard deviation of a dynamic dilution calibration normalized data point near the middle of the calibration dynamic range. Precision uncertainty is less than $7 \%$ for most species reported in Table 2. Detection limits for the various species (DL; Table 2) may be calculated in units of pptv analyte using the sum of a preci- 
Table 2. VOC species measured by iWAS/ACCBAR during SONGNEX. For each compound, the instrument channel, nonlinearity (Nonlin.; as described in the text, the ratio $\mathrm{A}:$ Sens $_{0}$ ), calibration standard accuracy (Cal acc.), calibration fit uncertainty (Fit unc.), precision and total uncertainty (Total Unc.) are reported.

\begin{tabular}{|c|c|c|c|c|c|c|}
\hline Compound & Channel & Nonlin. & $\begin{array}{r}\text { Cal acc. } \\
(\%)\end{array}$ & $\begin{array}{r}\text { Fit unc. } \\
(\%)\end{array}$ & $\begin{array}{r}\text { Precision } \\
(\%)\end{array}$ & $\begin{array}{l}\text { Total Unc. } \\
(\% \pm \text { pptv })\end{array}$ \\
\hline Ethane & 1 & - & 15 & 3.5 & 8 & $17+0.6$ \\
\hline Propane & 1 & - & 6 & 2.1 & 6 & $9+3$ \\
\hline i-Butane & 1 & 0.19 & 6 & 2.4 & 5 & $8+1$ \\
\hline n-Butane & 1 & 0.23 & 6 & 2.3 & 5 & $8+0.8$ \\
\hline i-Pentane & 1 & 0.33 & 6 & 1.6 & 3 & $7+0.8$ \\
\hline n-Pentane & 1 & 0.33 & 6 & 2.3 & 3 & $7+0.8$ \\
\hline n-Hexane & 1 & 0.34 & 6 & 3.9 & 4 & $8+5$ \\
\hline n-Hexane & 2 & 0.31 & 6 & 1.3 & 3 & $7+1$ \\
\hline n-Heptane & 2 & 0.39 & 6 & 2.5 & 4 & $8+0.8$ \\
\hline n-Octane & 2 & 0.53 & 6 & 2.0 & 3 & $7+1$ \\
\hline n-Nonane & 2 & 0.64 & 6 & 3.4 & 5 & $9+2$ \\
\hline Ethene & 1 & - & 6 & 3.4 & 8 & $11+3$ \\
\hline Isoprene & 1 & 0.32 & 6 & 3.5 & 7 & $10+3$ \\
\hline$\alpha$ Pinene & 2 & 0.64 & 6 & 2.8 & 1 & $7+1$ \\
\hline$\beta$ Pinene & 2 & 0.64 & 6 & 6.9 & 1 & $9+2$ \\
\hline Ethyne & 1 & 0.16 & 6 & 1.7 & 5 & $8+0.5$ \\
\hline Methylcyclopentane & 2 & & 6 & & 3 & 7 \\
\hline Cyclohexane & 2 & 0.29 & 6 & 1.4 & 4 & $7+2$ \\
\hline Methylcyclohexane & 2 & 0.44 & 6 & 2.7 & 5 & $8+1$ \\
\hline Benzene & 2 & 0.20 & 6 & 1.3 & 2 & $6+0.6$ \\
\hline Toluene & 2 & 0.34 & 6 & 3.0 & 4 & $8+2$ \\
\hline Ethylbenzene & 2 & 0.54 & 6 & 3.1 & 6 & $9+1$ \\
\hline m, p-Xylenes & 2 & 0.59 & 6 & 3.5 & 2 & $7+1$ \\
\hline o-Xylene & 2 & 0.52 & 6 & 2.8 & 4 & $8+1$ \\
\hline Nitrate, ethyl & 2 & 0.32 & 6 & 6.6 & 2 & $9+4$ \\
\hline Nitrate, i-propyl & 2 & 0.38 & 6 & 5.8 & 2 & $9+3$ \\
\hline Nitrate, n-propyl & 2 & 0.38 & 6 & 6.0 & 2 & $9+4$ \\
\hline Methanol & 2 & 0.49 & 6 & 3.0 & 4 & $8+15$ \\
\hline Ethanol & 2 & 0.77 & 6 & 1.8 & 4 & $7+12$ \\
\hline Acetone & 2 & 0.22 & 6 & 0.9 & 2 & $6+5$ \\
\hline Methyl ethyl ketone & 2 & 0.25 & 6 & 0.4 & 1 & $6+3$ \\
\hline Methyl vinyl ketone & 2 & 0.27 & 6 & 0.8 & 2 & $6+5$ \\
\hline Acetaldehyde & 2 & 0.32 & 6 & 3.6 & 3 & $8+8$ \\
\hline Propanal & 2 & - & 6 & 1.6 & 2 & $7+3$ \\
\hline Methacrolein & 2 & 0.30 & 6 & 0.6 & 2 & $6+3$ \\
\hline
\end{tabular}

sion estimate and the instrument sensitivity:

$\mathrm{DL}=3 \times \sigma_{\text {prec }} \times$ Sens,

where $\sigma_{\text {prec }}$ is the standard deviation of the lowest calibration point (minimum four replicates) for any reported species in units of nkcts and Sens is the instrument sensitivity for that species, in units of pptv nkct ${ }^{-1}$ (Oliver et al., 1996). An example chromatogram is shown in the Supplement (Fig. S4) for a calibration measurement at $26 \mathrm{pptv}$ mixing ratio of the 57-component PAMS mixture described in Sect. 3.2. For most species, the detection limit is less than or equal to 5 pptv and often below 1 pptv, but ACCBAR had significantly higher limits of detection for several oxygenated species. The humidification system used during dynamic di- lutions contributes significant backgrounds for some oxygenated species (e.g., alcohols) and thereby increasing the standard deviation of those calibration points. Total analytic uncertainty for each reported species is the sum in quadrature of the uncertainties of the calibration standard and sensitivity function and the precision. Total uncertainty must also account for absolute uncertainty at low mixing ratios as the $\mathrm{DL}$, so that our total uncertainty is stated as relative uncertainty $(\%)+$ absolute uncertainty (pptv). Total uncertainty for all species is listed in Table 2. Other than ethane (17\%), the range of relative analytical uncertainties for species reported ranges between 6 and $11 \%$ and is typically less than $10 \%$. 

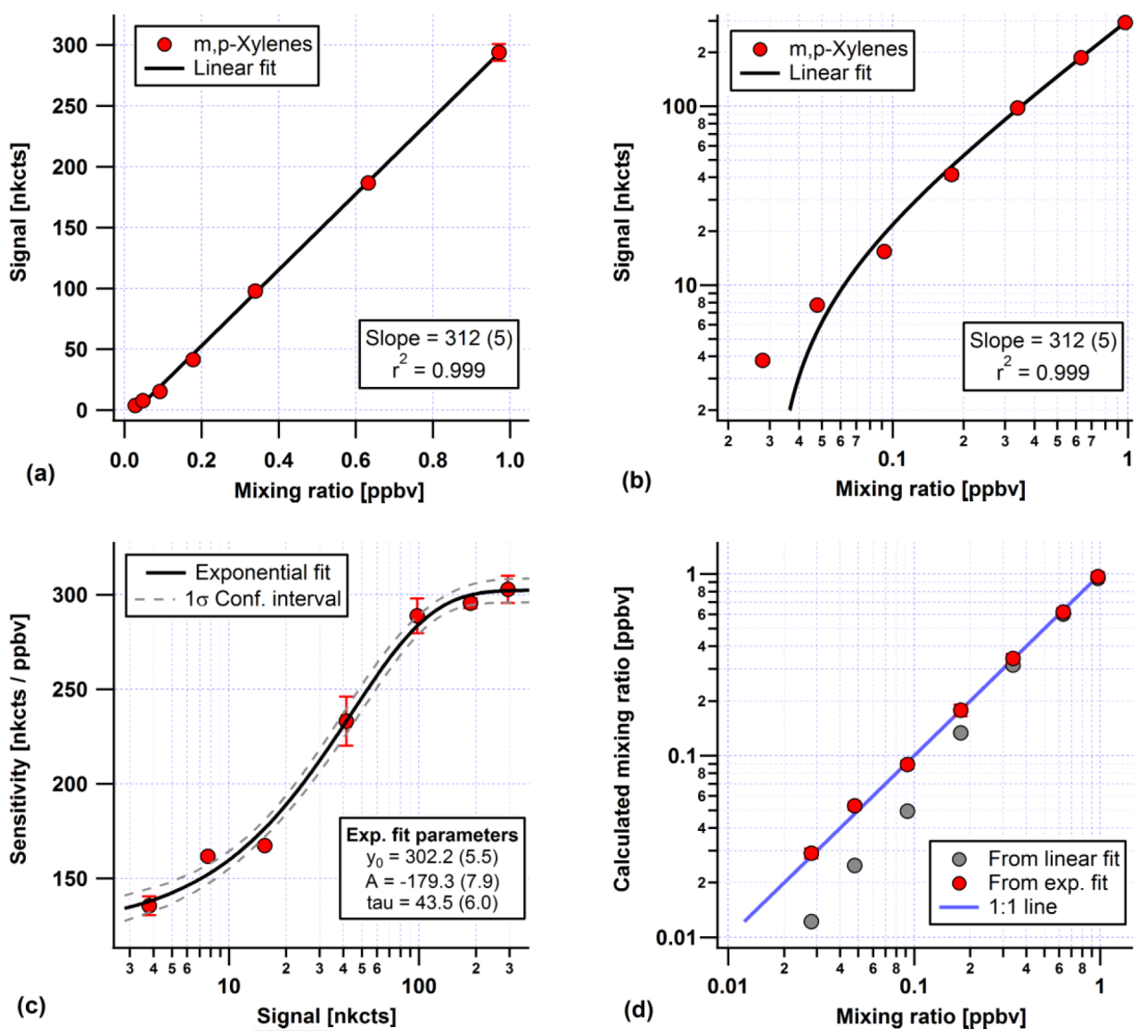

Figure 5. Example nonlinear sensitivity calibration for $\mathrm{m}$, p-xylenes. Panels (a) and (b) show a linear fit of normalized signal versus mixing ratio for a seven-point calibration, using linear and log scaling of the same data. In panel (c) an exponential function has been fit to sensitivity calculated at each calibration point versus normalized counts. Panel (d) shows mixing ratio calculated from both the linear fit and the exponential fit of sensitivity plotted against actual mixing ratio. Values in parentheses are $1 \sigma$ uncertainties of fit coefficients.

To assess the overall analytical uncertainty further, the measurements of n-hexane, which is quantified on both channels of the GC-MS, are compared. Figure 6 shows a scatter plot of n-hexane measurements for the entire SENEX field campaign. The two-sided linear fit of the data indicates an agreement within $4 \%$ with an insignificant intercept and little scatter (a least-squares fit gives a correlation coefficient, $r$, of 0.98).

\subsection{Sample canister tests}

Previous work (Kelly and Holdren, 1995; Ochiai et al., 2002; Palluau et al., 2005) has indicated that samples collected in dry electropolished stainless steel canisters may be subject to significant artifacts due to loss of certain VOCs to the canister walls, while samples humidified either via addition of water prior to sampling or by adequate ambient water vapor will be less prone to these effects. The iWAS/ACCBAR system was evaluated for potential artifacts due to canister preparation, sample collection and sample aging. This was accomplished via four sets of tests.

\subsubsection{Canister humidification and retrieval efficiency}

A series of humidification experiments were performed using ambient air samples collected outside the laboratory in Boulder, $\mathrm{CO}$, in canisters filled with varying amounts of water vapor after the cleaning process (Fig. 7). The goal of these tests was to determine the minimum level of water vapor that should be added to the sample canisters in order to sufficiently reduce analyte losses to the canister surfaces. ACCBAR collected and measured the ambient air in situ while canister were simultaneously filled, using a common PFA inlet for both systems. Ambient dew points during these tests varied between -1 and $5{ }^{\circ} \mathrm{C}(15-40 \% \mathrm{RH})$, while air temperature was between 21 and $28^{\circ} \mathrm{C}$. Fill times for the canisters were approximately $30 \mathrm{~s}$; these extended fill times were achieved by restricting the inlet flow to the compressor and opening multiple canisters at the same time. Canisters were evaluated for retrieval efficiency (Rtv Eff), which is defined as the ratio of canister mixing ratios to in situ mixing ratios 


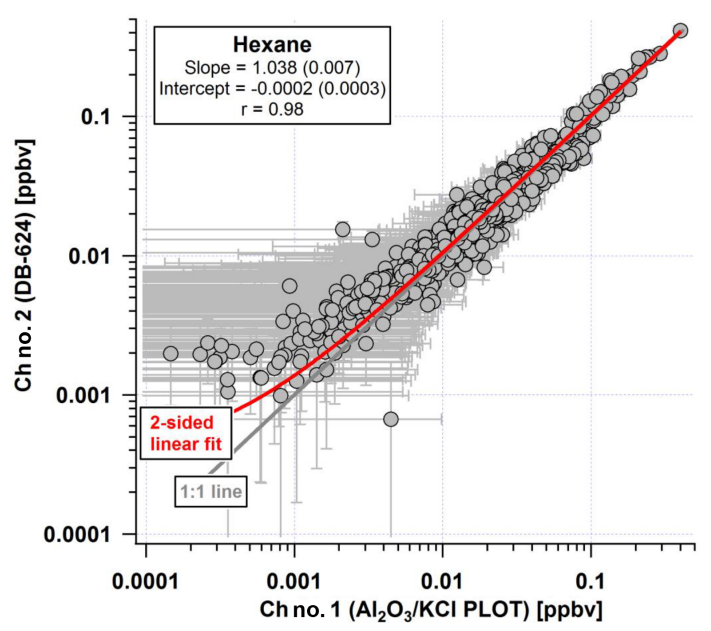

Figure 6. Intercomparison of n-hexane measurements made by the two different channels of iWAS/ACCBAR system during SENEX 2013. Data are shown with error bars based upon total analytical uncertainty presented in Table 2.

for samples collected at approximately the same time.

$$
\begin{gathered}
\text { RtvEff }=\text { mean concentration canister/ } \\
\text { mean concentration in situ }
\end{gathered}
$$

Most hydrocarbons show retrieval efficiencies near unity, with considerable scatter due to the difficulty in comparing a 4 min integrated sample (in situ) with a $30 \mathrm{~s}$ integrated sample (canister). For most species, water vapor pressure $>10$ torr $(13 \mathrm{hPa})$ was found to be adequate to passivate the canisters, although heavy aromatics ( $>\mathrm{C} 8)$ showed significant losses at all levels. Ketones are positively correlated with added water, indicating a possible contamination with the canister humidification system.

\subsubsection{Canister blanks}

During SONGNEX, the sampling system was evaluated for background signal by filling canisters with zero air immediately after cleaning and humidifying, then allowing the cans to sit 1-3 days before analysis. These tests are in contrast to the analysis system blanks (see Sect. 2.2.1) as they identify signal enhancements attributable to canister preparation. These results are presented in Table 3 as blanks in units of pptv. Hydrocarbons and alkyl nitrates have very small signals in the blanks, with ethane being the only species with a mixing ratio greater than 2 pptv. However, a few oxygenated species had blank values at atmospherically relevant levels. The blanks were significantly larger than the analysis system blanks (the same zero air passed through the sample train) so the artifacts are attributed to the canisters rather than the analysis system. Since nearly all species but oxygenates were below detection limit, the canister cleaning appears to be adequate. Instead, the source of contamination is likely the canister humidification system, confirming the observations noted in Sect. 3.4.1. Because of this contamination, oxygenates are not reported for SONGNEX. For SENEX, sample canisters were pre-treated not with water vapor but with humidified nitrogen (see Sect. 2.2.3), so mixing ratios of oxygenates collected in the planetary boundary layer are expected to be less perturbed for this dataset. Also note that during SONGNEX, ACCBAR showed a significant ethanol contamination that decayed exponentially throughout the campaign, so that the reported ethanol blank value here is likely a combination of instrument and canister artifact.

\subsubsection{Canister aging and retrieval efficiency}

Additional canister tests were conducted to characterize the retrieval efficiencies and short-term storage $(<100 \mathrm{~h})$ effects of the iWAS/ACCBAR system using canisters prepared with approximately 12 torr of water vapor. For each sample period, four to nine canisters were filled with air collected from outside the Boulder, CO, laboratory while ACCBAR simultaneously measured the air in situ, similar to that in described in Sect. 3.4.1. The ambient dew point during these tests was near $8{ }^{\circ} \mathrm{C}(45-55 \% \mathrm{RH})$ with an air temperature around $18^{\circ} \mathrm{C}$. Due to the configuration of the canister sampling geometry, the canister fill times are not expected to be identical, but rather the first canister in the sample path will fill to full pressure slightly before the next canister. This results in larger variance sample to sample than replicate tests (see Sect. 3.4.4), especially for compounds with transient ambient mixing ratios (e.g., aromatics and alkenes due to local auto exhaust). The large variance between canisters and simultaneous ambient measurements has previously been reported (Plass-Dülmer et al., 2006). The canister samples were then measured 1,2 and 4 days after collection. Two example plots are shown in Fig. 8, the results are summarized in Table 3 and all test results are listed in Tables S2 and S3 in the Supplement. At $95 \%$ confidence interval (mean $+2 \sigma)$, there were only two differences in Rtv Eff between the canisters after 1,2 or 4 days of aging across all compounds (Table S2), in agreement with the replicate tests described in Sect. 3.4.1. Therefore, the data for these canister tests were grouped together irrespective of age to calculate a single Rtv Eff for each compound, which are shown in Table 3. Generally, hydrocarbon retrieval efficiencies vary near or slightly above unity, with no alkane, alkene or cycloalkane having a Rtv Eff significantly different than 1 . Aromatic species and alkyl nitrates have Rtv Eff that are systematically low, although typically within $20 \%$ of the in situ measurement. Oxygenated species were not well-behaved, with aldehydes and ketones showing large scatter, excluding methyl ethyl ketone and methacrolein. As noted above, the canister humidification system is the suspected source of this contamination. Further work will be required to identify the cause of this contamination in the humidification flow path and eliminate it. 

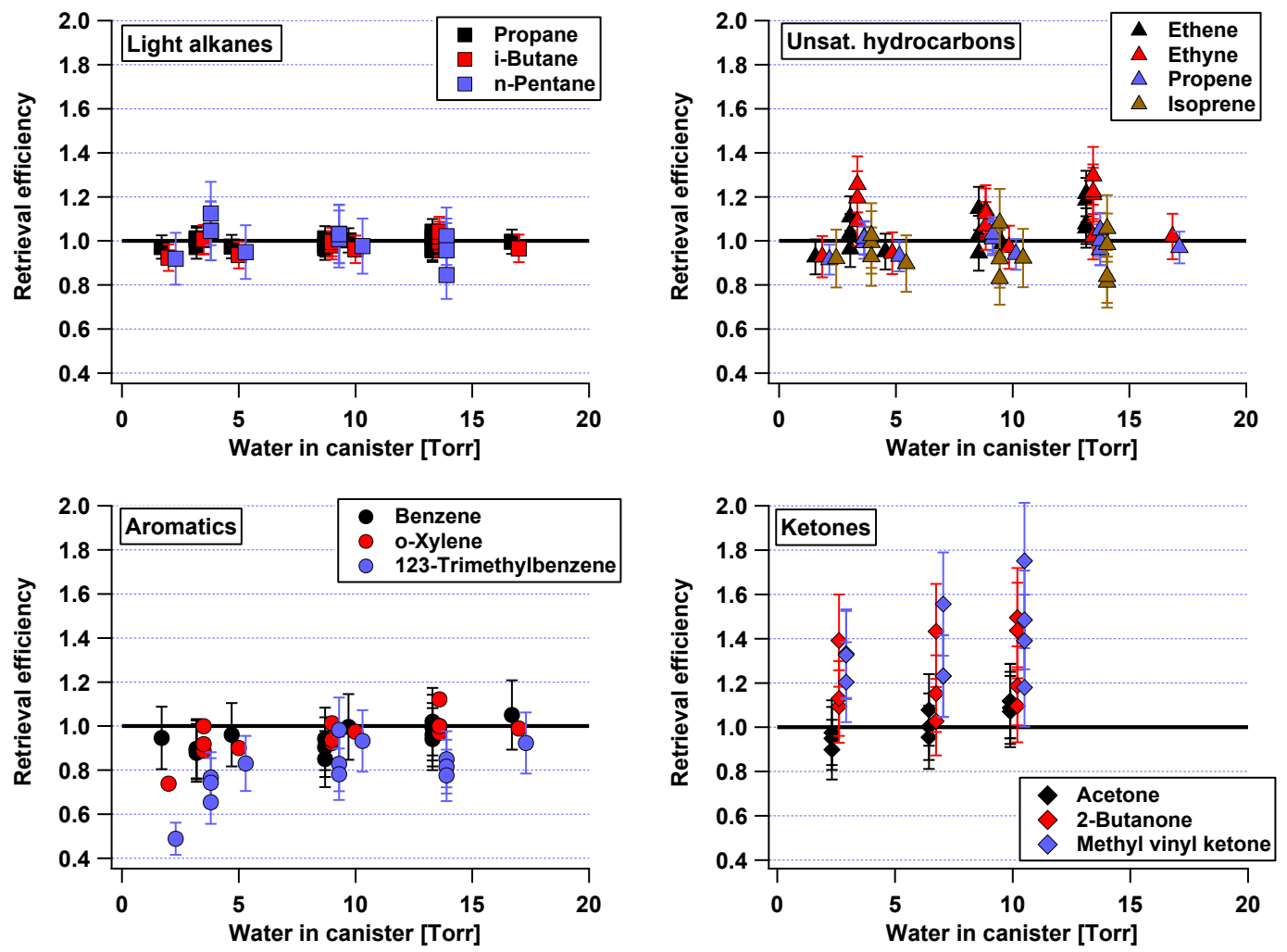

Figure 7. Retrieval efficiency as a function of added water vapor to sample canisters after cleaning. Data points are the ratio of observed mixing ratios in canister samples versus ambient mixing ratios measured by ACCBAR during the time period the canisters were filled. Error bars indicate standard deviation of multiple canisters filled simultaneously. Data are offset on $x$ axis for easier viewing.
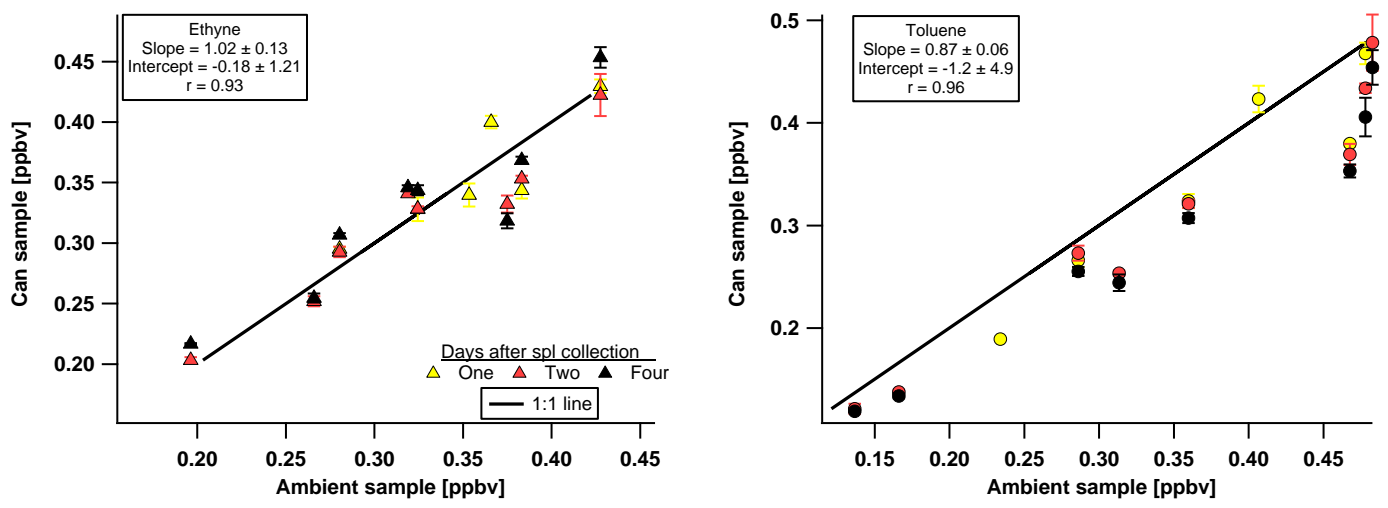

Figure 8. Canister samples versus in situ ambient samples collected in Boulder, CO, using sample canisters humidified to 12 torr water vapor during the cleaning process. Error bars indicate standard deviation of replicate canister samples.

\subsubsection{Canister replicates}

During SONGNEX replicate analysis was performed on full sets of canister samples from three research flights to evaluate the analytical precision of the entire system (rather than just the GC-MS). The research flights were made on 9 April through the eastern Permian Basin of Texas, on 13 April in the Denver-Julesburg Basin and Colorado Front Range and on 23 April through the western Permian Basin of Texas and
New Mexico. These canister sets were aged on average 37, 256 and $92 \mathrm{~h}$, respectively, between the first and second analysis. Example scatter plots comparing the first and second analysis are shown in Fig. 9. For most species, the replicates were not significantly different than unity for the 37 and $92 \mathrm{~h}$ replicates, with the notable exception of alcohols which were enhanced for the second analysis due to temporary partitioning into the aqueous phase (Kelly and Holdren, 1995). Repli- 
Table 3. VOC species measured by iWAS/ACCBAR during SONGNEX. Canister backgrounds (Blank), replicates and retrieval efficiencies (Rtv Eff) and total uncertainties are reported. Replicate compares two analyses of the same sample canister performed within $100 \mathrm{~h}$ of each other. Retrieval efficiency (Rtv Eff) is the ratio of the observed mixing ratio between canister and in situ samples collected simultaneously, with the canisters then analyzed within $100 \mathrm{~h}$ of collection. Total uncertainty is reported as $\%+$ pptv.

\begin{tabular}{|c|c|c|c|c|c|}
\hline Compound & Channel & $\begin{array}{l}\text { Blank } \\
\text { (pptv) }\end{array}$ & Replicate & Rtv Eff & $\begin{array}{l}\text { Total Unc } \\
(\% \pm \text { pptv })\end{array}$ \\
\hline Ethane & 1 & $6(1)$ & $0.98(0.01)$ & $1.06(0.14)$ & $18+2$ \\
\hline Propane & 1 & B.D.L. & $0.93(0.01)$ & $1.05(0.21)$ & $12+3$ \\
\hline i-Butane & 1 & $0.9(0.3)$ & $0.95(0.01)$ & $\mathrm{n} / \mathrm{a}$ & $10+2$ \\
\hline n-Butane & 1 & B.D.L. & $0.97(0.01)$ & $1.13(0.07)$ & $16+1$ \\
\hline i-Pentane & 1 & B.D.L. & $0.97(0.01)$ & $0.95(0.07)$ & $9+1$ \\
\hline n-Pentane & 1 & B.D.L. & $0.99(0.01)$ & $1.04(0.06)$ & $8+1$ \\
\hline n-Hexane & 1 & B.D.L. & $0.98(0.01)$ & $0.95(0.04)$ & $10+5$ \\
\hline n-Hexane & 2 & B.D.L. & $1.01(0.01)$ & $0.94(0.06)$ & $9+1$ \\
\hline n-Heptane & 2 & B.D.L. & $0.97(0.01)$ & $1.07(0.10)$ & $11+1$ \\
\hline n-Octane & 2 & B.D.L. & $0.97(0.01)$ & $1.09(0.11)$ & $12+1$ \\
\hline n-Nonane & 2 & B.D.L. & $0.98(0.01)$ & $1.05(0.07)$ & $10+2$ \\
\hline Ethene & 1 & B.D.L. & $0.98(0.01)$ & $1.05(0.33)$ & $12+3$ \\
\hline Isoprene & 1 & B.D.L. & $1.11(0.03)$ & $0.98(0.06)$ & $15+3$ \\
\hline$\alpha$ Pinene & 2 & B.D.L. & $0.92(0.35)$ & $1.05(0.09)$ & $12+1$ \\
\hline$\beta$ Pinene & 2 & B.D.L. & $\mathrm{n} / \mathrm{a}$ & $1.16(0.10)$ & $18+2$ \\
\hline Ethyne & 1 & B.D.L. & $1.02(0.01)$ & $1.02(0.08)$ & $8+1$ \\
\hline Methylcyclopentane & 2 & B.D.L. & $1.06(0.01)$ & $1.13(0.08)$ & 16 \\
\hline Cyclohexane & 2 & B.D.L. & $1.11(0.02)$ & $1.18(0.09)$ & $22+2$ \\
\hline Methylcyclohexane & 2 & B.D.L. & $0.94(0.01)$ & $1.03(0.08)$ & $11+1$ \\
\hline Benzene & 2 & $0.5(0.1)$ & $0.97(0.01)$ & $0.99(0.07)$ & $7+1$ \\
\hline Toluene & 2 & B.D.L. & $0.96(0.01)$ & $0.87(0.06)$ & $16+2$ \\
\hline Ethylbenzene & 2 & B.D.L. & $0.95(0.01)$ & $0.92(0.09)$ & $13+1$ \\
\hline $\mathrm{m}, \mathrm{p}$-Xylenes & 2 & B.D.L. & $0.94(0.01)$ & $0.78(0.08)$ & $24+1$ \\
\hline o-Xylene & 2 & B.D.L. & $0.98(0.01)$ & $0.82(0.08)$ & $20+1$ \\
\hline Nitrate, ethyl & 2 & B.D.L. & $0.96(0.01)$ & $0.98(0.14)$ & $10+4$ \\
\hline Nitrate, i-propyl & 2 & B.D.L. & $1.00(0.01)$ & $0.87(0.02)$ & $16+3$ \\
\hline Nitrate, n-propyl & 2 & B.D.L. & $1.00(0.01)$ & $0.91(0.07)$ & $13+4$ \\
\hline Methanol & 2 & $100(50)$ & $1.28(0.02)$ & $1.6(1.3)$ & $67+50$ \\
\hline Ethanol & 2 & $600(150)$ & $1.35(0.02)$ & $1.26(0.15)$ & $44+150$ \\
\hline Acetone & 2 & $180(110)$ & $0.95(0.03)$ & $-0.8(85)$ & 100 \\
\hline Methyl ethyl ketone & 2 & $25(25)$ & $0.95(0.01)$ & $1.03(0.12)$ & $8+25$ \\
\hline Methyl vinyl ketone & 2 & $12(5)$ & $1.06(0.01)$ & $32(154)$ & 100 \\
\hline Acetaldehyde & 2 & $390(280)$ & $1.07(0.02)$ & $31(32)$ & 100 \\
\hline Propanal & 2 & $40(40)$ & $0.95(0.03)$ & $42(76)$ & 100 \\
\hline Methacrolein & 2 & B.D.L. & $1.11(0.02)$ & $1.25(0.16)$ & $28+3$ \\
\hline
\end{tabular}

cate results for aldehyde and ketone species typically agreed within $10 \%$, indicating that the analysis system does not contribute measurement artifacts for these species. For cans aged $256 \mathrm{~h}$ on average, several additional classes of compounds (ketones, alkyl nitrates, aromatics) showed enhancements in the second analysis. For SONGNEX, most canisters (92\%) were analyzed within $100 \mathrm{~h}$ of sampling, so only the 37 and $92 \mathrm{~h}$ replicate results are considered to be applicable here. The results of these tests are summarized in Table 3 as the slope of the two-sided linear regression of the combined 37 and $92 \mathrm{~h}$ replicates, ignoring the $256 \mathrm{~h}$ replicate samples.

\subsubsection{Total uncertainty}

Using the information from the canister tests and the total analytical uncertainty reported in Sect. 3.3, we can describe the total uncertainty for measurements reported from the iWAS/ACCBAR system for SONGNEX, reported as relative plus absolute uncertainty $(\%+$ pptv). For each compound, total relative uncertainty for the canisters is the quadrature summed analytical relative uncertainty and percentage differences of the replicate and Rtv Eff. Absolute uncertainty is the quadrature sum of analytical DL and the standard deviation of the canister blanks. Relative uncertainties for the canister measurements reported here typically range be- 

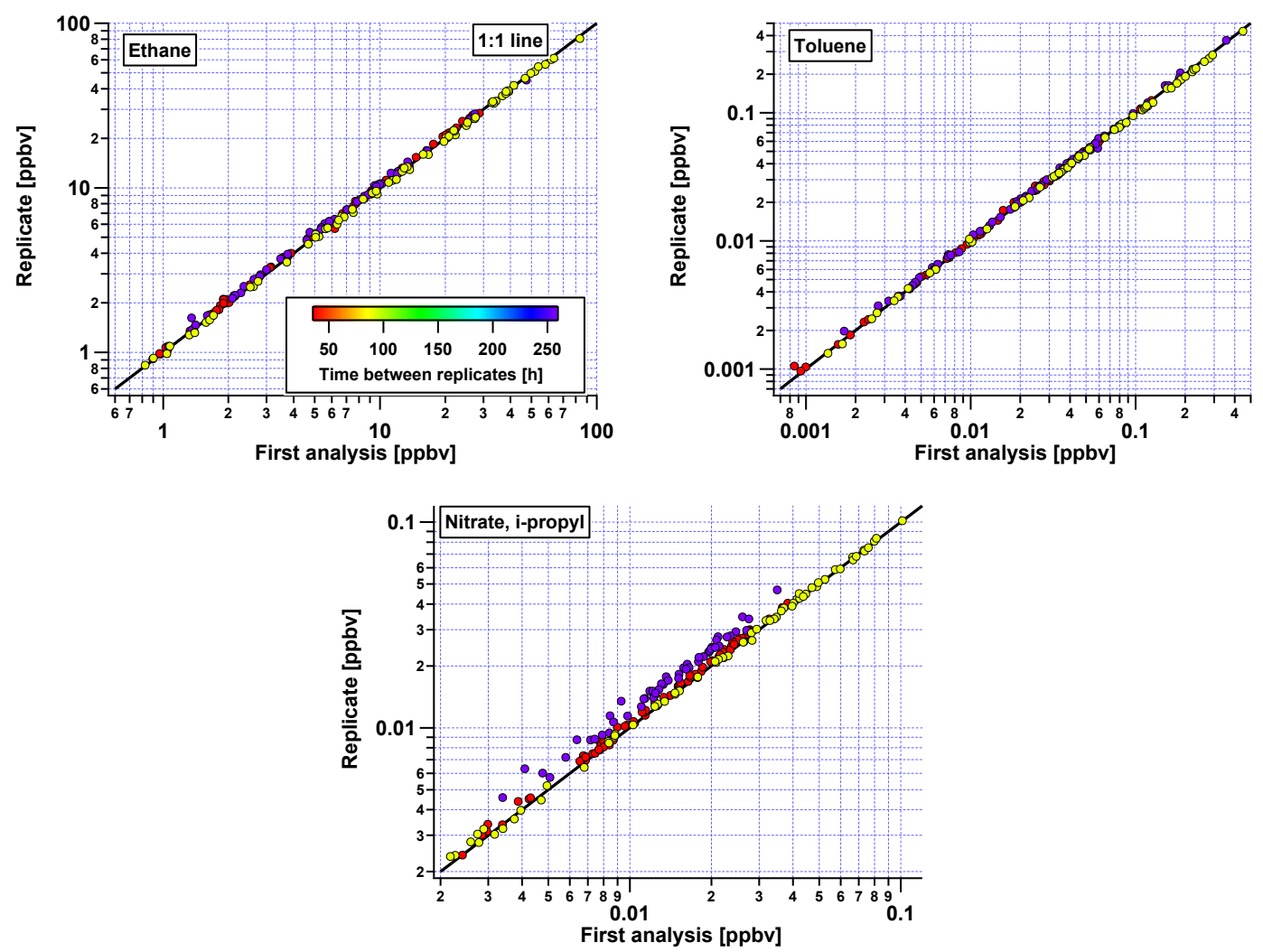

Figure 9. Comparison of replicate analyses from the same sample canister sets from three flights during SONGNEX 2015 (flight dates: 9 , 13, 23 April).

tween 10 and $20 \%$ for hydrocarbons and alkyl nitrates. During SONGNEX, most oxygenated species had significantly larger uncertainties due to uncertain retrieval efficiencies, with only methyl ethyl ketone and methacrolein having acceptable uncertainty levels. Further canister testing evaluations are required to determine if improved canister preparation and handling will allow for reduced uncertainties of oxygenated species.

\section{Results: measurement validation by intercomparison with other measurements}

\subsection{SENEX 2013}

The iWAS/ACCBAR system was first field-deployed for the SENEX field campaign in the southeastern USA in latespring 2013, where canister samples were collected aboard the NOAA WP-3D aircraft. As described in Sect. 2.2.3, the canisters were not filled with water vapor but rather with humidified UHP $\mathrm{N}_{2}$, as the typical boundary layer humidity levels were adequate to produce condensed water in the sample canisters at sample fill pressures. One set of three canister modules was not humidified at all but was flown entirely evacuated during a test flight from Tampa, FL; these can- isters were not considered for the orthogonal fits of the data discussed below. During the field campaign, a proton transfer reaction mass spectrometer (PTRMS; de Gouw et al., 2003) also flew aboard the NOAA WP-3D and measured 12 VOCs (individually or as grouped response by mass) using a nominal $15 \mathrm{~s}$ duty cycle, measuring an individual unit mass for one second. Intercomparisons between the PTRMS and previous whole air sampling systems have been published (de Gouw and Warneke, 2007) showing generally good agreement for aromatic species summed by carbon number, isoprene and select oxygenates, with correlation coefficients typically between 0.85 and 0.95 .

Due to the large ambient variability of some species, additional scatter in the data is expected from the difficulty of time-aligning these two measurements. Canister sample fill times were less than $8 \mathrm{~s}$ for more than $95 \%$ of all samples during SENEX, so the comparison requires a $15 \mathrm{~s}$ averaging window of PTRMS data centered about the midpoint of the canister fill time. For SENEX, six individual or summed species measured by both instruments are compared, as shown in Fig. 10a-f. Light aromatic species (benzene and toluene) showed a significant difference in slope between the instruments, with the iWAS mixing ratios lower than the PTRMS. The trend is consistent with observed retrieval efficiency of toluene noted during the canister tests 

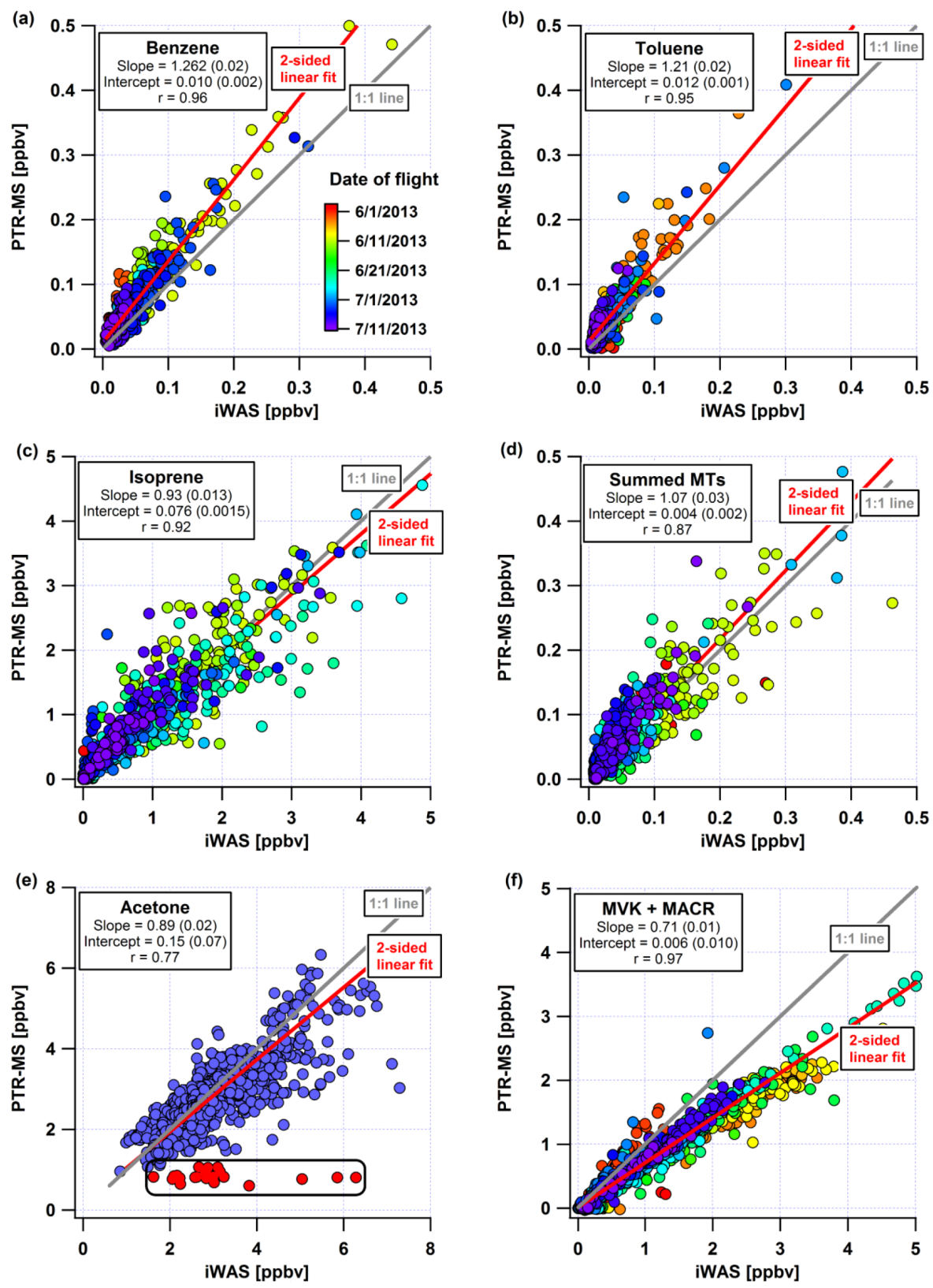

Figure 10. Intercomparison with PTRMS of select VOCs from SENEX 2013. Slopes and intercepts from two-sided linear fits of the data are presented, along with correlation coefficients $(r)$ from one-sided linear fits. The red points circled in (e) show data collected in dry canisters during a test flight from Tampa, FL, and are not used for the linear fits.

discussed above, but significant benzene losses in canisters have not been observed. Biogenic species were abundant in ambient air during SENEX, and the comparison between instruments compares favorably to previous published work (de Gouw and Warneke, 2007) for both isoprene and summed monoterpenes (i.e., $\alpha$ pinene, $\beta$ pinene, 3 -carene and limonene from the canister measurements vs. $m / z 137$ for the PTRMS; de Gouw et al., 2015). Intercomparisons of acetone and the summed response of methyl vinyl ketone and methacrolein both show a significant difference in slope between the instruments, with the canister system showing a higher response than the PTRMS, especially for MVK + MACR. Interestingly, the 36 dry canisters - circled in Fig. 10e - have a pronounced enhanced signal for acetone, but the MVK+MACR scatter plot does not show the same response. Recent work has found that oxidation products of isoprene may contribute to artificial response in the whole air canister system, and the retrieval efficiency experiments indicated a particular enhancement of MVK in the iWAS canisters, consistent with modeling results (Rivera- 

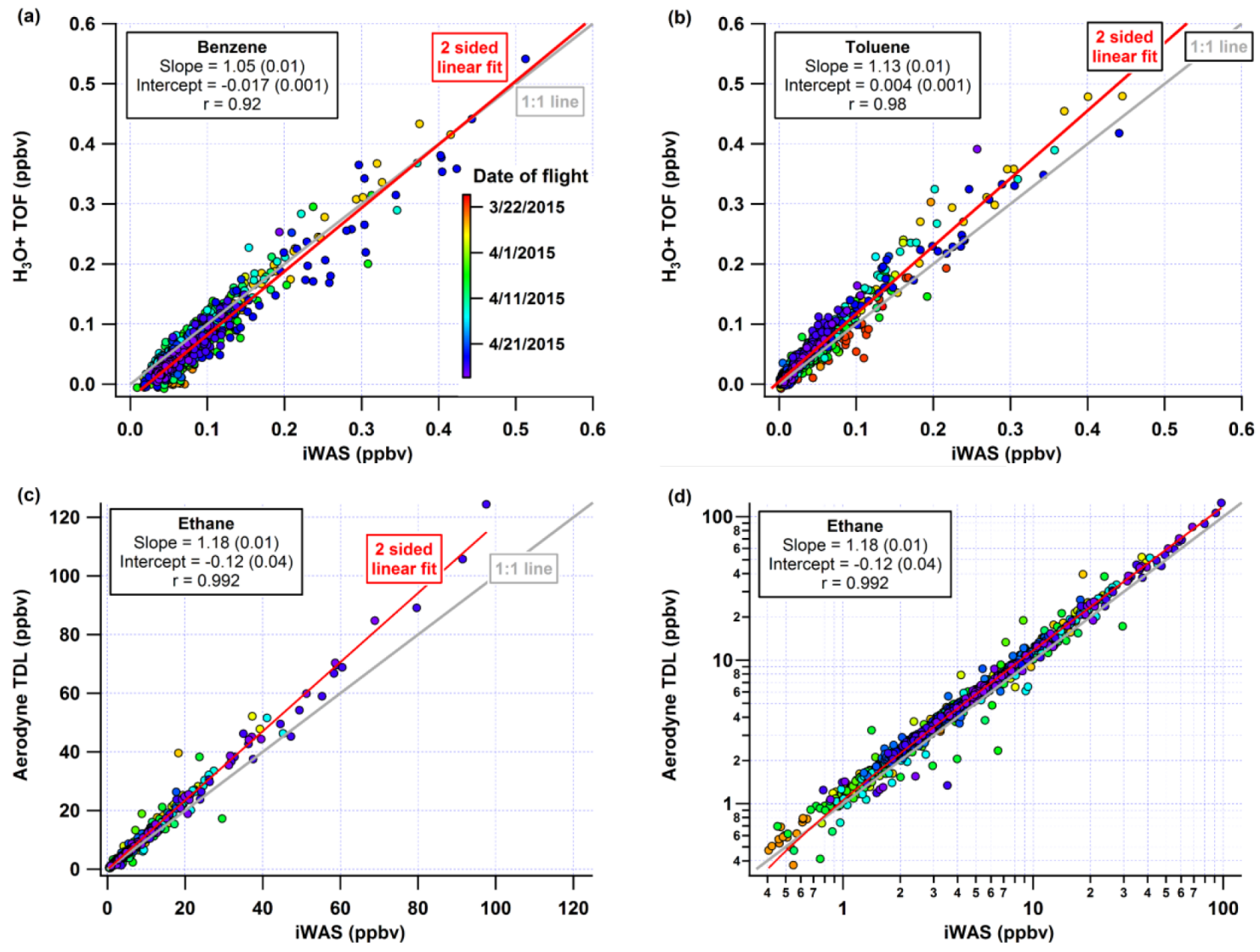

Figure 11. (a-b) Intercomparison with $\mathrm{H}_{3} \mathrm{O}^{+}$-CIMS of benzene and toluene, respectively, from SONGNEX 2015. Slopes and intercepts from two-sided linear fits of the data are presented, along with correlation coefficients $(r)$ from one-sided linear fits. (c-d) Ethane intercomparison for SONGNEX 2015. Slopes and intercepts from two-sided linear fits of the data are presented, along with correlation coefficients $(r)$ from one-sided linear fits.
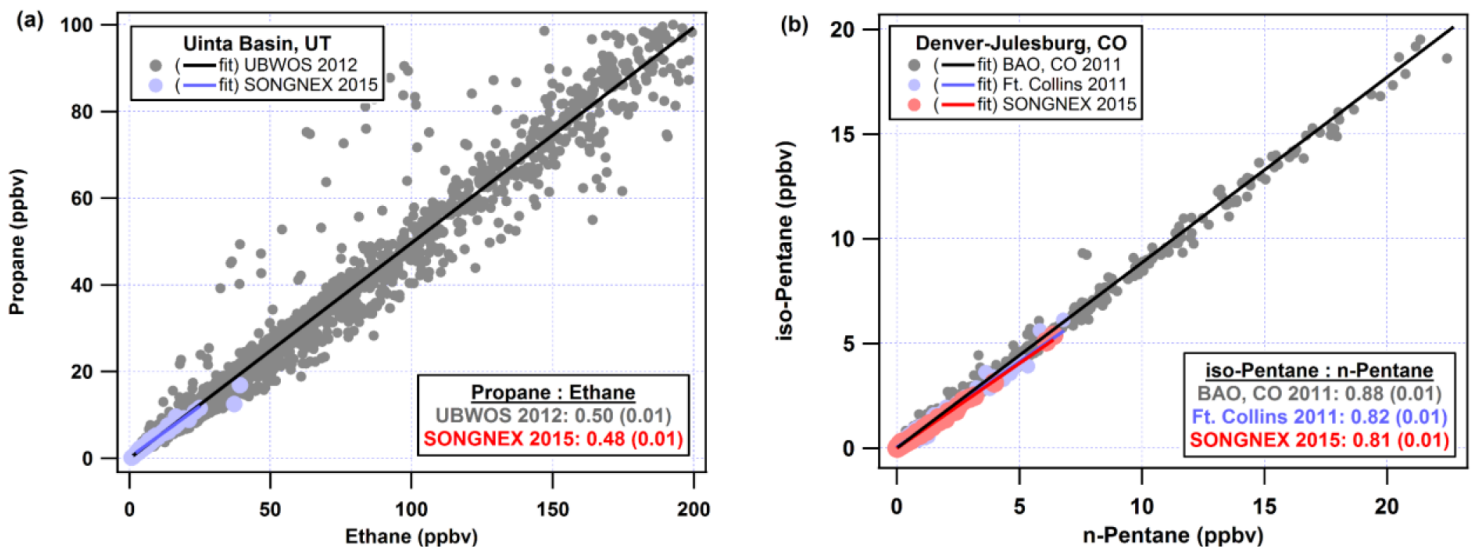

Figure 12. Intercomparison of alkane measurements made in oil and natural gas fields using a ground-based in situ GC-MS (Uinta Basin, UT (UBWOS 2012), Boulder Atmospheric Observatory (BAO; NACHTT 2011), Ft. Collins, CO (BIOCORN 2011)) and airborne WAS during SONGNEX 2015.

Rios et al., 2014; Wolfe et al., 2016). Therefore, the difference between instruments for MVK+MACR is attributed to enhanced response of MVK. Note that all species reported here have a correlation coefficient greater than 0.85 , with the exception of acetone, comparable to previous intercompar- 
isons between whole air samplers and PTRMS techniques cited above.

\subsection{SONGNEX 2015}

For SONGNEX, a more limited set of intercomparisons with other instruments is available due to the apparent contamination of the canister during preparation by oxygenated species (see Sect. 3.4) and due to the ambient mixing ratios of observed species (isoprene and monoterpenes were at low mixing ratios during early spring). The PTRMS instrument that had been used for previous field missions was replaced with a new hydronium-ion chemical ionization time-of-flight mass spectrometer $\left(\mathrm{H}_{3} \mathrm{O}^{+}\right.$-CIMS; Yuan et al., 2016). A new spectroscopic-based ethane detector (Yacovitch et al., 2014) was also aboard the NOAA WP-3D aircraft, providing an additional compound for intercomparison. Light aromatic species (benzene and toluene) were measured by both iWAS/ACCBAR and the $\mathrm{H}_{3} \mathrm{O}^{+}$-CIMS, and scatter plots of these mixing ratios are shown in Fig. 11a-b. The benzene slope is insignificantly different from one given the stated uncertainties of the instruments, while the $\mathrm{H}_{3} \mathrm{O}^{+}$CIMS observed slightly higher toluene mixing ratios, which is in line with the results of the canister tests described in Sect. 3.4. Comparison of ethane measurements (Fig. 11c-d) shows a very tightly correlated measurement with a significant difference in slope (higher response by the spectroscopic instrument). This discrepancy is partially attributable to an inconsistency on the order of $15 \%$ within the ethane calibration scales used for the two instruments. If a single calibration scale is applied to both instruments, the measurements agree within $8 \%$, which is within the stated uncertainty for ACCBAR.

The intercomparisons with in situ instruments presented here show significant scatter, especially when compared to recent WAS validation work (Apel et al., 2003a; Hoerger et al., 2015). It should be recognized that the scatter in the data shown here is not unique, but it is typical in other presentations of comparisons between in situ and WAS measurements aboard aircraft (de Gouw et al., 2006; Hornbrook et al., 2011), as well as ground-based comparisons with fast time response and GC-MS systems (de Gouw et al., 2003; Plass-Dülmer et al., 2006; Pollmann et al., 2008).

An alternative evaluation for the quality of measurements made with the canister system is possible by comparing measurements made in the same airshed by different instruments at different times. Absolute mixing ratios are expected to vary with time, but ratios of species with high emission rates and relatively slow atmospheric reaction rates are expected to be stable if emission sources are consistent over the time period of the intercomparison. Research flights made during SONGNEX overflew two shale basins that had been recently characterized by NOAA CSD using an older GC-MS system: Uinta Basin in Utah (Warneke et al., 2014) and DenverJulesburg in Colorado (Gilman et al., 2013). Figure 12a-b show intercomparisons of two different pairs of alkanes from the Uinta Basin and Denver-Julesburg fields, respectively. The ratio of propane to ethane, determined by the slope of a two-sided linear fit, was statistically equivalent for the Uinta Basin between 2012 and 2015, although the absolute mixing ratios observed during the ground-based campaign are considerably higher than the aircraft measurements. For DenverJulesburg, two sets of ground-based measurements have previously been reported: wintertime measurements made at the southwest edge of the oil and gas exploration area (BAO, $\mathrm{CO}$ ) and summertime measurements made at the northwest edge of the area near Ft. Collins, CO. The ratio of isopentane to n-pentane determined by a two-sided linear fit for the SONGNEX flight data is statistically equivalent to the Fort Collins, $\mathrm{CO}$, data, but the $\mathrm{BAO}, \mathrm{CO}$, data have a slightly higher ratio. The difference for the $\mathrm{BAO}, \mathrm{CO}$, data may be due to the difference in season affecting the relative oxidation rates of isopentane and n-pentane or the influence of the nearby Denver metropolitan area where the isopentane to npentane ratio is higher because of gasoline emissions from mobile sources.

\section{Conclusions}

A new automated whole air sampler and GC-MS analysis system that relies upon cryogenic sample pre-concentration without the need for liquid nitrogen has been designed, built and field-deployed. The whole air sampler typically fills 72 sample canisters during a single research flight; post-flight analysis requires $30 \mathrm{~h}$ with minimal interaction with the operator. A new peak integration software package allows for the automated retrieval of peak areas, thereby reducing postanalysis data processing time by an order of magnitude. Over 2400 air samples were analyzed during the SENEX 2013 and SONGNEX 2015 field campaigns, with mixing ratios reported for a wide range of hydrocarbons (alkanes, alkenes, aromatics), alkyl nitrates, monoterpenes and select oxygenated species. The GC-MS analytical system limit of detection is typically below one part per trillion with total uncertainty (at $1 \sigma$ ) less than $10 \%$. With the whole air sampler, total uncertainty for reported species increased to between 8 and $24 \%$ for hydrocarbons and alkyl nitrates. Significant sampling artifacts were observed from the canister samples for several classes of oxygenated species (aldehydes, ketones, alcohols) along with significant losses of heavy aromatics $(\mathrm{C} 9+)$. Intercomparison with other measurements indicates good results for light aromatics and biogenic hydrocarbons, with improved agreement for the SONGNEX 2015 campaign. 


\section{Data availability}

The field data presented here are available from the NOAA ESRL CSD data server, listed by field campaign: 2011 NACHTT (https://esrl.noaa.gov/csd/groups/csd7/ measurements/2011NACHTT/Tower/DataDownload/);

2011 BIOCORN (https://esrl.noaa.gov/csd/groups/csd7/ measurements/2011biocorn/Ground/DataDownload/);

2012 UBWOS (https://esrl.noaa.gov/csd/groups/csd7/ measurements/2012ubwos/Ground/DataDownload/);

2013 SENEX (https://esrl.noaa.gov/csd/groups/csd7/ measurements/2013senex/P3/DataDownload/); 2015 SONGNEX (https://esrl.noaa.gov/csd/groups/csd7/ measurements/2015songnex/P3/DataDownload/).

\section{The Supplement related to this article is available online at doi:10.5194/amt-10-291-2017-supplement.}

Competing interests. The authors declare that they have no conflict of interest.

Acknowledgements. The authors would like to thank the staffs of NOAA's Aircraft Operations Center and the Design and Fabrication Services shop of NCAR's Earth Observing Laboratory for their assistance with the work described in this paper. We thank Courtney Hatch, Alyssa Jaksish and Degan Hughes of Hendrix College and Megan Dumas of Stonehill College (now at UC Irvine) for their assistance with collecting and reducing data for SENEX. We thank William Dubé of the NOAA ESRL CSD laboratory for fruitful discussions of various engineering strategies employed in the analysis system. We thank Allen Goldstein and Doug Wornsop for their support in the development of TERN.

Edited by: E. C. Apel

Reviewed by: A.-C. Lewis and one anonymous referee

\section{References}

Apel, E. C., Calvert, J. G., Gilpin, T. M., Fehsenfeld, F., and Lonneman, W. A.: Nonmethane Hydrocarbon Intercomparison Experiment (NOMHICE): Task 4, ambient air, J. Geophys. Res.Atmos., 108, 4300, doi:10.1029/2002JD002936, $2003 \mathrm{a}$.

Apel, E. C., Hills, A. J., Lueb, R., Zindel, S., Eisele, S., and Riemer, D. D.: A fast-GC/MS system to measure C-2 to C-4 carbonyls and methanol aboard aircraft, J. Geophys. Res.-Atmos., 108, doi:10.1029/2002jd003199, 2003 b.

Blake, D. R., Smith, T. W., Chen, T. Y., Whipple, W. J., and Rowland, F. S.: Effects of biomass burning on summertime nonmethane hydrocarbon concentrations in the Canadian wetlands, J. Geophys. Res.-Atmos., 99, 1699-1719, doi:10.1029/93jd02598, 1994.
Brown, R. H. and Purnell, C. J.: Collection and analysis of trace organic vapour pollutants in ambient atmospheres, J. Chromatogr. A, 178, 79-90, doi:10.1016/S0021-9673(00)89698-3, 1979.

Colman, J. J., Swanson, A. L., Meinardi, S., Sive, B. C., Blake, D. R., and Rowland, F. S.: Description of the analysis of a wide range of volatile organic compounds in whole air samples collected during PEM-Tropics A and B, Anal. Chem., 73, 37233731, doi:10.1021/ac010027g, 2001.

de Gouw, J. and Warneke, C.: Measurements of volatile organic compounds in the earths atmosphere using proton-transferreaction mass spectrometry, Mass Spectrom. Rev., 26, 223-257, doi:10.1002/mas.20119, 2007.

de Gouw, J. A., Goldan, P. D., Warneke, C., Kuster, W. C., Roberts, J. M., Marchewka, M., Bertman, S. B., Pszenny, A. A. P., and Keene, W. C.: Validation of proton transfer reaction-mass spectrometry (PTR-MS) measurements of gas-phase organic compounds in the atmosphere during the New England Air Quality Study (NEAQS) in 2002, J. Geophys. Res.-Atmos., 108, 4682, doi:10.1029/2003jd003863, 2003.

de Gouw, J. A., Middlebrook, A. M., Warneke, C., Goldan, P. D., Kuster, W. C., Roberts, J. M., Fehsenfeld, F. C., Worsnop, D. R., Canagaratna, M. R., Pszenny, A. A. P., Keene, W. C., Marchewka, M., Bertman, S. B., and Bates, T. S.: Budget of organic carbon in a polluted atmosphere: Results from the New England Air Quality Study in 2002, J. Geophys. Res.-Atmos., 110, D16305, doi:10.1029/2004JD005623, 2005.

de Gouw, J. A., Warneke, C., Stohl, A., Wollny, A. G., Brock, C. A., Cooper, O. R., Holloway, J. S., Trainer, M., Fehsenfeld, F. C., Atlas, E. L., Donnelly, S. G., Stroud, V., and Lueb, A.: Volatile organic compounds composition of merged and aged forest fire plumes from Alaska and western Canada, J. Geophys. Res.-Atmos., 111, D10303, doi:10.1029/2005JD006175, 2006.

de Gouw, J. A., McKeen, S. A., Aikin, K. C., Brock, C. A., Brown, S. S., Gilman, J. B., Graus, M., Hanisco, T., Holloway, J. S., Kaiser, J., Keutsch, F. N., Lerner, B. M., Liao, J., Markovic, M. Z., Middlebrook, A. M., Min, K. E., Neuman, J. A., Nowak, J. B., Peischl, J., Pollack, I. B., Roberts, J. M., Ryerson, T. B., Trainer, M., Veres, P. R., Warneke, C., Welti, A., and Wolfe, G. M.: Airborne measurements of the atmospheric emissions from a fuel ethanol refinery, J. Geophys. Res.-Atmos., 120, 4385-4397, doi:10.1002/2015jd023138, 2015.

de Waele, A. T. A. M.: Basic Operation of Cryocoolers and Related Thermal Machines, J. Low Temp. Phys., 164, 179-236, doi:10.1007/s10909-011-0373-x, 2011.

Edwards, P. M., Brown, S. S., Roberts, J. M., Ahmadov, R., Banta, R. M., deGouw, J. A., Dube, W. P., Field, R. A., Flynn, J. H., Gilman, J. B., Graus, M., Helmig, D., Koss, A., Langford, A. O., Lefer, B. L., Lerner, B. M., Li, R., Li, S.-M., McKeen, S. A., Murphy, S. M., Parrish, D. D., Senff, C. J., Soltis, J., Stutz, J., Sweeney, C., Thompson, C. R., Trainer, M. K., Tsai, C., Veres, P. R., Washenfelder, R. A., Warneke, C., Wild, R. J., Young, C. J., Yuan, B., and Zamora, R.: High winter ozone pollution from carbonyl photolysis in an oil and gas basin, Nature, 514, 351354, doi:10.1038/nature13767, 2014.

Fortin, T. J., Howard, B. J., Parrish, D. D., Goldan, P. D., Kuster, W. C., Atlas, E. L., and Harley, R. A.: Temporal Changes in US Benzene Emissions Inferred from Atmospheric Measurements, Environ. Sci. Technol., 39, 1403-1408, doi:10.1021/es049316n, 2005. 
Gentner, D. R., Ormeño, E., Fares, S., Ford, T. B., Weber, R., Park, J.-H., Brioude, J., Angevine, W. M., Karlik, J. F., and Goldstein, A. H.: Emissions of terpenoids, benzenoids, and other biogenic gas-phase organic compounds from agricultural crops and their potential implications for air quality, Atmos. Chem. Phys., 14, 5393-5413, doi:10.5194/acp-14-5393-2014, 2014.

Gilman, J. B., Lerner, B. M., Kuster, W. C., and de Gouw, J. A.: Source Signature of Volatile Organic Compounds from Oil and Natural Gas Operations in Northeastern Colorado, Environ. Sci. Technol., 47, 1297-1305, doi:10.1021/es304119a, 2013.

Gilman, J. B., Lerner, B. M., Kuster, W. C., Goldan, P. D., Warneke, C., Veres, P. R., Roberts, J. M., de Gouw, J. A., Burling, I. R., and Yokelson, R. J.: Biomass burning emissions and potential air quality impacts of volatile organic compounds and other trace gases from fuels common in the US, Atmos. Chem. Phys., 15, 13915-13938, doi:10.5194/acp-15-13915-2015, 2015.

Glasius, M. and Goldstein, A. H.: Recent Discoveries and Future Challenges in Atmospheric Organic Chemistry, Environ. Sci. Technol., 50, 2754-2764, doi:10.1021/acs.est.5b05105, 2016.

Goldan, P. D., Kuster, W. C., Fehsenfeld, F. C., and Montzka, S. A.: Hydrocarbon measurements in the southeastern United States: The Rural Oxidants in the Southern Environment (ROSE) Program 1990, J. Geophys. Res.-Atmos., 100, 25945-25963, doi:10.1029/95JD02607, 1995.

Goldan, P. D., Parrish, D. D., Kuster, W. C., Trainer, M., McKeen, S. A., Holloway, J., Jobson, B. T., Sueper, D. T., and Fehsenfeld, F. C.: Airborne measurements of isoprene, $\mathrm{CO}$, and anthropogenic hydrocarbons and their implications, J. Geophys. Res.-Atmos., 105, 9091-9105, doi:10.1029/1999JD900429, 2000.

Goldan, P. D., Kuster, W. C., Williams, E., Murphy, P. C., Fehsenfeld, F. C., and Meagher, J.: Nonmethane hydrocarbon and oxy hydrocarbon measurements during the 2002 New England Air Quality Study, J. Geophys. Res.-Atmos., 109, D21309, doi:10.1029/2003jd004455, 2004.

Greenberg, J. P., Lee, B., Helmig, D., and Zimmerman, P. R.: Fully automated gas chromatograph-flame ionization detector system for the in situ determination of atmospheric nonmethane hydrocarbons at low parts per trillion concentration, J. Chromatogr. A, 676, 389-398, doi:10.1016/0021-9673(94)80439-7, 1994.

Heidt, L. E., Vedder, J. F., Pollock, W. H., Lueb, R. A., and Henry, B. E.: Trace Gases in the Antarctic Atmosphere, J. Geophys. Res.-Atmos., 94, 11599-11611, doi:10.1029/JD094iD09p11599, 1989.

Hoerger, C. C., Claude, A., Plass-Duelmer, C., Reimann, S., Eckart, E., Steinbrecher, R., Aalto, J., Arduini, J., Bonnaire, N., Cape, J. N., Colomb, A., Connolly, R., Diskova, J., Dumitrean, P., Ehlers, C., Gros, V., Hakola, H., Hill, M., Hopkins, J. R., Jäger, J., Junek, R., Kajos, M. K., Klemp, D., Leuchner, M., Lewis, A. C., Locoge, N., Maione, M., Martin, D., Michl, K., Nemitz, E., O’Doherty, S., Pérez Ballesta, P., Ruuskanen, T. M., Sauvage, S., Schmidbauer, N., Spain, T. G., Straube, E., Vana, M., Vollmer, M. K., Wegener, R., and Wenger, A.: ACTRIS non-methane hydrocarbon intercomparison experiment in Europe to support WMO GAW and EMEP observation networks, Atmos. Meas. Tech., 8, 2715-2736, doi:10.5194/amt-8-2715-2015, 2015.

Hopkins, J. R., Jones, C. E., and Lewis, A. C.: A dual channel gas chromatograph for atmospheric analysis of volatile organic compounds including oxygenated and monoterpene compounds, J.
Environ. Monitor., 13, 2268-2276, doi:10.1039/C1EM10050E, 2011.

Hornbrook, R. S., Blake, D. R., Diskin, G. S., Fried, A., Fuelberg, H. E., Meinardi, S., Mikoviny, T., Richter, D., Sachse, G. W., Vay, S. A., Walega, J., Weibring, P., Weinheimer, A. J., Wiedinmyer, C., Wisthaler, A., Hills, A., Riemer, D. D., and Apel, E. C.: Observations of nonmethane organic compounds during ARCTAS - Part 1: Biomass burning emissions and plume enhancements, Atmos. Chem. Phys., 11, 11103-11130, doi:10.5194/acp11-11103-2011, 2011.

Hoyle, C. R., Myhre, G., Berntsen, T. K., and Isaksen, I. S. A.: Anthropogenic influence on SOA and the resulting radiative forcing, Atmos. Chem. Phys., 9, 2715-2728, doi:10.5194/acp-9-27152009, 2009.

Isaacman-VanWertz, G., Sueper, D. T., Gilman, J. B., Aiken, K. C., Lerner, B. M., deGouw, J. A., Worsnop, D. R., and Goldstein, A. H.: Efficient and improved reduction of chromatographic data using single-ion peak fitting and deconvolution, J. Chromatogr. A, in preparation, 2017.

Kanakidou, M., Seinfeld, J. H., Pandis, S. N., Barnes, I., Dentener, F. J., Facchini, M. C., Van Dingenen, R., Ervens, B., Nenes, A., Nielsen, C. J., Swietlicki, E., Putaud, J. P., Balkanski, Y., Fuzzi, S., Horth, J., Moortgat, G. K., Winterhalter, R., Myhre, C. E. L., Tsigaridis, K., Vignati, E., Stephanou, E. G., and Wilson, J.: Organic aerosol and global climate modelling: a review, Atmos. Chem. Phys., 5, 1053-1123, doi:10.5194/acp-5-1053-2005, 2005.

Karbiwnyk, C. M., Mills, C. S., Helmig, D., and Birks, J. W.: Use of Chlorofluorocarbons as Internal Standards for the Measurement of Atmospheric Non-Methane Volatile Organic Compounds Sampled onto Solid Adsorbent Cartridges, Environ. Sci. Technol., 37, 1002-1007, doi:10.1021/es025910q, 2003.

Kelly, T. J. and Holdren, M. W.: Applicability of canisters for sample storage in the determination of hazardous airpollutants, Atmos. Environ., 29, 2595-2608, doi:10.1016/13522310(95)00192-2, 1995.

Liu, C. T., Mu, Y. J., Zhang, C. L., Zhang, Z. B., Zhang, Y. Y., Liu, J. F., Sheng, J. J., and Quan, J. N.: Development of gas chromatography-flame ionization detection system with a single column and liquid nitrogen-free for measuring atmospheric C2-C12 hydrocarbons, J. Chromatogr. A, 1427, 134-141, doi:10.1016/j.chroma.2015.11.060, 2016.

McClenny, W. A., Pleil, J. D., Holdren, M. W., and Smith, R. N.: Automated cryogenic preconcentration and gas-chromatographic determination of volatile organic-compounds in air, Anal. Chem., 56, 2947-2951, doi:10.1021/ac00278a073, 1984.

McClenny, W. A., Pleil, J. D., Evans, G. F., Oliver, K. D., Holdren, M. W., and Winberry, W. T.: Canister-based methods for monitoring toxic VOCs in ambient air, J. Air Waste Manage. Assoc., 41, 1308-1318, 1991

McClenny, W. A., Oliver, K. D., and Adams, J. R.: EPA Method TO-15 VOCs in Air Collected in SUMMA (Trade Name) Canisters and Analyzed by Gas Chromatography/Mass Spectrometry, ManTech Environmental Technology, Inc., Research Triangle Park, NC., Environmental Protection Agency, Research Triangle Park, NC., 1996.

Mckeen, S. A. and Liu, S. C.: Hydrocarbon Ratios and Photochemical History of Air Masses, Geophys. Res. Lett., 20, 2363-2366, 1993. 
Miller, B. R., Weiss, R. F., Salameh, P. K., Tanhua, T., Greally, B. R., Muhle, J., and Simmonds, P. G.: Medusa: A sample preconcentration and GC/MS detector system for in situ measurements of atmospheric trace halocarbons, hydrocarbons, and sulfur compounds, Anal. Chem., 80, 1536-1545, doi:10.1021/ac702084k, 2008.

Monks, P. S., Archibald, A. T., Colette, A., Cooper, O., Coyle, M., Derwent, R., Fowler, D., Granier, C., Law, K. S., Mills, G. E., Stevenson, D. S., Tarasova, O., Thouret, V., von Schneidemesser, E., Sommariva, R., Wild, O., and Williams, M. L.: Tropospheric ozone and its precursors from the urban to the global scale from air quality to short-lived climate forcer, Atmos. Chem. Phys., 15, 8889-8973, doi:10.5194/acp-15-8889-2015, 2015.

Montzka, S. A., McFarland, M., Andersen, S. O., Miller, B. R., Fahey, D. W., Hall, B. D., Hu, L., Siso, C., and Elkins, J. W.: Recent Trends in Global Emissions of Hydrochlorofluorocarbons and Hydrofluorocarbons: Reflecting on the 2007 Adjustments to the Montreal Protocol, J. Phys. Chem. A, 119, 4439-4449, doi:10.1021/jp5097376, 2015.

Obersteiner, F., Bönisch, H., and Engel, A.: An automated gas chromatography time-of-flight mass spectrometry instrument for the quantitative analysis of halocarbons in air, Atmos. Meas. Tech., 9, 179-194, doi:10.5194/amt-9-179-2016, 2016.

Ochiai, N., Tsuji, A., Nakamura, N., Daishima, S., and Cardin, D. B.: Stabilities of 58 volatile organic compounds in fused-silica-lined and SUMMA polished canisters under various humidified conditions, J. Environ. Monitor., 4, 879-889, doi:10.1039/b209210g, 2002.

Oliver, K. D., Adams, J. R., Daughtrey, E. H., McClenny, W. A., Yoong, M. J., and Pardee, M. A.: Technique for monitoring ozone precursor hydrocarbons in air at photochemical assessment monitoring stations: Sorbent preconcentration, closed-cycle cooler cryofocusing, and GC-FID analysis, Atmos. Environ., 30, 27512757, doi:10.1016/1352-2310(95)00371-1, 1996.

Palluau, F., Mirabel, P., and Millet, M.: A dynamic dilution systembased evaluation of the procedure adopted for determining ozone precursor volatile compounds, Anal. Bioanal. Chem., 381, 742761, doi:10.1007/s00216-004-2980-8, 2005.

Parrish, D. D., Allen, D. T., Bates, T. S., Estes, M., Fehsenfeld, F. C., Feingold, G., Ferrare, R., Hardesty, R. M., Meagher, J. F., Nielsen-Gammon, J. W., Pierce, R. B., Ryerson, T. B., Seinfeld, J. H., and Williams, E. J.: Overview of the Second Texas Air Quality Study (TexAQS II) and the Gulf of Mexico Atmospheric Composition and Climate Study (GoMACCS), J. Geophys. Res.Atmos., 114, D00F13, doi:10.1029/2009JD011842, 2009.

Plass-Dülmer, C., Schmidbauer, N., Slemr, J., Slemr, F., and D'Souza, H.: European hydrocarbon intercomparison experiment AMOHA part 4: Canister sampling of ambient air, J. Geophys. Res.-Atmos., 111, D04306, doi:10.1029/2005JD006351, 2006.

Pollmann, J., Helmig, D., Hueber, J., Plass-Dülmer, C., and Tans, P.: Sampling, storage, and analysis of $\mathrm{C} 2-\mathrm{C} 7$ nonmethane hydrocarbons from the US National Oceanic and Atmospheric Administration Cooperative Air Sampling Network glass flasks, J. Chromatogr. A, 1188, 75-87, doi:10.1016/j.chroma.2008.02.059, 2008.

Rivera-Rios, J. C., Nguyen, T. B., Crounse, J. D., Jud, W., St. Clair, J. M., Mikoviny, T., Gilman, J. B., Lerner, B. M., Kaiser, J. B., de Gouw, J., Wisthaler, A., Hansel, A., Wennberg, P. O., Sein- feld, J. H., and Keutsch, F. N.: Conversion of hydroperoxides to carbonyls in field and laboratory instrumentation: Observational bias in diagnosing pristine versus anthropogenically controlled atmospheric chemistry, Geophys. Res. Lett., 41, 86458651, doi:10.1002/2014GL061919, 2014.

Sala, S., Bönisch, H., Keber, T., Oram, D. E., Mills, G., and Engel, A.: Deriving an atmospheric budget of total organic bromine using airborne in situ measurements from the western Pacific area during SHIVA, Atmos. Chem. Phys., 14, 6903-6923, doi:10.5194/acp-14-6903-2014, 2014.

Schauffler, S. M., Atlas, E. L., Blake, D. R., Flocke, F., Lueb, R. A., Lee-Taylor, J. M., Stroud, V., and Travnicek, W.: Distributions of brominated organic compounds in the troposphere and lower stratosphere, J. Geophys. Res.-Atmos., 104, 21513-21535, doi:10.1029/1999JD900197, 1999.

Schultz M. G., Bottenheim, J., Buchmann, B., Galbally, I. E., Gilge, S., Helmig, D., Koide, H., Lewis, A. C., Novelli, P. C., Plass-Dülmer, C., Ryerson, T. B., Steinbacher, M., Steinbrecher, R., Tarsova, O., Tørseth, K., Thouret, V., and Zellweger, C.: The Global Atmosphere Watch reactive gases measurement network, Elem. Sci. Anth., 3, 000067 , doi:10.12952/journal.elementa.000067, 2015.

Simpson, I. J., Blake, N. J., Barletta, B., Diskin, G. S., Fuelberg, H. E., Gorham, K., Huey, L. G., Meinardi, S., Rowland, F. S., Vay, S. A., Weinheimer, A. J., Yang, M., and Blake, D. R.: Characterization of trace gases measured over Alberta oil sands mining operations: 76 speciated $\mathrm{C}_{2}-\mathrm{C}_{10}$ volatile organic compounds (VOCs), $\mathrm{CO}_{2}, \mathrm{CH}_{4}, \mathrm{CO}, \mathrm{NO}, \mathrm{NO}_{2}, \mathrm{NO}_{y}, \mathrm{O}_{3}$ and $\mathrm{SO}_{2}$, Atmos. Chem. Phys., 10, 11931-11954, doi:10.5194/acp-10-11931-2010, 2010.

Simpson, I. J., Aburizaiza, O. S., Siddique, A., Barletta, B., Blake, N. J., Gartner, A., Khwaja, H., Meinardi, S., Zeb, J., and Blake, D. R.: Air Quality in Mecca and Surrounding Holy Places in Saudi Arabia During Hajj: Initial Survey, Environ. Sci. Technol., 48, 8529-8537, doi:10.1021/es5017476, 2014.

Sive, B. C., Zhou, Y., Troop, D., Wang, Y. L., Little, W. C., Wingenter, O. W., Russo, R. S., Varner, R. K., and Talbot, R.: Development of a cryogen-free concentration system for measurements of volatile organic compounds, Anal. Chem., 77, 69896998, doi:10.1021/ac0506231, 2005.

Tanner, D., Helmig, D., Hueber, J., and Goldan, P.: Gas chromatography system for the automated, unattended, and cryogenfree monitoring of $\mathrm{C} 2$ to $\mathrm{C} 6$ non-methane hydrocarbons in the remote troposphere, J. Chromatogr. A, 1111, 76-88, doi:10.1016/j.chroma.2006.01.100, 2006.

ter Brake, H. J. M. and Wiegerinck, G. F. M.: Low-power cryocooler survey, Cryogenics, 42, 705-718, doi:10.1016/S00112275(02)00143-1, 2002.

Trainer, M., Parrish, D. D., Goldan, P. D., Roberts, J., and Fehsenfeld, F. C.: Review of observation-based analysis of the regional factors influencing ozone concentrations, Atmos. Environ., 34, 2045-2061, 2000.

Wang, D. K. W. and Austin, C. C.: Determination of complex mixtures of volatile organic compounds in ambient air: canister methodology, Anal. Bioanal. Chem., 386, 1099-1120, doi:10.1007/s00216-006-0466-6, 2006.

Wang, J.-L., Chang, C.-C., and Lee, K.-Z.: In-line sampling with gas chromatography-mass spectrometry to monitor ambient volatile organic compounds, J. Chromatogr. A, 1248, 161-168, doi:10.1016/j.chroma.2012.05.091, 2012. 
Wang, M., Zeng, L., Lu, S., Shao, M., Liu, X., Yu, X., Chen, W., Yuan, B., Zhang, Q., Hu, M., and Zhang, Z.: Development and validation of a cryogen-free automatic gas chromatograph system (GC-MS/FID) for online measurements of volatile organic compounds, Analytical Methods, 6, 9424-9434, doi:10.1039/c4ay01855a, 2014.

Warneke, C., de Gouw, J. A., Holloway, J. S., Peischl, J., Ryerson, T. B., Atlas, E., Blake, D., Trainer, M., and Parrish, D. D.: Multiyear trends in volatile organic compounds in Los Angeles, California: Five decades of decreasing emissions, J. Geophys. Res.-Atmos., 117, D00V17, doi:10.1029/2012JD017899, 2012.

Warneke, C., Geiger, F., Edwards, P. M., Dube, W., Pétron, G., Kofler, J., Zahn, A., Brown, S. S., Graus, M., Gilman, J. B., Lerner, B. M., Peischl, J., Ryerson, T. B., de Gouw, J. A., and Roberts, J. M.: Volatile organic compound emissions from the oil and natural gas industry in the Uintah Basin, Utah: oil and gas well pad emissions compared to ambient air composition, Atmos. Chem. Phys., 14, 10977-10988, doi:10.5194/acp14-10977-2014, 2014.

Warneke, C., Trainer, M., de Gouw, J. A., Parrish, D. D., Fahey, D. W., Ravishankara, A. R., Middlebrook, A. M., Brock, C. A., Roberts, J. M., Brown, S. S., Neuman, J. A., Lerner, B. M., Lack, D., Law, D., Hübler, G., Pollack, I., Sjostedt, S., Ryerson, T. B., Gilman, J. B., Liao, J., Holloway, J., Peischl, J., Nowak, J. B., Aikin, K. C., Min, K.-E., Washenfelder, R. A., Graus, M. G., Richardson, M., Markovic, M. Z., Wagner, N. L., Welti, A., Veres, P. R., Edwards, P., Schwarz, J. P., Gordon, T., Dube, W. P., McKeen, S. A., Brioude, J., Ahmadov, R., Bougiatioti, A., Lin, J. J., Nenes, A., Wolfe, G. M., Hanisco, T. F., Lee, B. H., LopezHilfiker, F. D., Thornton, J. A., Keutsch, F. N., Kaiser, J., Mao, J., and Hatch, C. D.: Instrumentation and measurement strategy for the NOAA SENEX aircraft campaign as part of the Southeast Atmosphere Study 2013, Atmos. Meas. Tech., 9, 3063-3093, doi:10.5194/amt-9-3063-2016, 2016.
WMO: GAW Report 204: Standard Operating Procedures (SOPs) for Air Sampling in Stainless Steel Canisters for Non-Methane Hydrocarbons Analysis, in: GAW, 204, World Meteorological Organization, Geneva, Switzerland, 24, 2012.

Wolfe, G. M., Kaiser, J., Hanisco, T. F., Keutsch, F. N., de Gouw, J. A., Gilman, J. B., Graus, M., Hatch, C. D., Holloway, J., Horowitz, L. W., Lee, B. H., Lerner, B. M., Lopez-Hilifiker, F., Mao, J., Marvin, M. R., Peischl, J., Pollack, I. B., Roberts, J. M., Ryerson, T. B., Thornton, J. A., Veres, P. R., and Warneke, C.: Formaldehyde production from isoprene oxidation across NOx regimes, Atmos. Chem. Phys., 16, 2597-2610, doi:10.5194/acp16-2597-2016, 2016.

Woolfenden, E.: Sorbent-based sampling methods for volatile and semi-volatile organic compounds in air: Part 1: Sorbent-based air monitoring options, J. Chromatogr. A, 1217, 2674-2684, doi:10.1016/j.chroma.2009.12.042, 2010.

Yacovitch, T. I., Herndon, S. C., Roscioli, J. R., Floerchinger, C., McGovern, R. M., Agnese, M., Pétron, G., Kofler, J., Sweeney, C., Karion, A., Conley, S. A., Kort, E. A., Nähle, L., Fischer, M., Hildebrandt, L., Koeth, J., McManus, J. B., Nelson, D. D., Zahniser, M. S., and Kolb, C. E.: Demonstration of an Ethane Spectrometer for Methane Source Identification, Environ. Sci. Technol., 48, 8028-8034, doi:10.1021/es501475q, 2014.

Yuan, B., Koss, A., Warneke, C., Gilman, J. B., Lerner, B. M., Stark, H., and de Gouw, J. A.: A high-resolution time-of-flight chemical ionization mass spectrometer utilizing hydronium ions $\left(\mathrm{H}_{3} \mathrm{O}^{+}\right.$ToF-CIMS) for measurements of volatile organic compounds in the atmosphere, Atmos. Meas. Tech., 9, 2735-2752, doi:10.5194/amt-9-2735-2016, 2016. 